Maurer School of Law: Indiana University

Digital Repository @ Maurer Law

Winter 2018

The Dragon-Kings' Restraint: Proposing a Compromise for the EEZ Surveillance Conundrum

Asaf Lubin

Follow this and additional works at: https://www.repository.law.indiana.edu/facpub

Part of the International Law Commons, and the Law of the Sea Commons 


\title{
The Dragon-Kings' Restraint: Proposing a Compromise for the EEZ Surveillance Conundrum
}

\author{
Asaf Lubin $^{\dagger}$
}

\begin{abstract}
The United States and China are at it again, as naval and aerial interceptions in and around the South China Sea become a matter of disturbing routine. At the heart of the dispute stands the lingering question of whether customary international law as reflected in the United Nations Convention on the Law of the Sea ("UNCLOS") authorizes third States to engage in surveillance and military maneuvers in coastal States' Exclusive Economic Zones ("EEZ") without their consent. The answer lies in interpreting Article 58(1) of UNCLOS.

This paper aims to respond to the calls put forward by States, scholars, and research institutes to promote a legal compromise between permissive and prohibitive interpretive approaches to UNCLOS Article 58(1). The traditional interpretation of the Article, and the EEZ Surveillance conundrum more broadly, has thus far been reviewed by scholars solely through the lenses of the age-old debate between Hugo Grotius and John Selden over Mare Liberum and Mare Clausum. In other words, existing scholarship treats the dispute as a binary zero-sum game.

The model proposed in the Article recognizes the freedom of navigation premise as an analytical starting point, but nonetheless introduces, for reasons of maintaining minimum order, a set of restraints ("necessity," "last resort," and "proportionality") to be internalized by third States in deciding whether to launch intelligence operations in another coastal State's EEZ. To develop these standards, the paper examines the limits of a State's right to spy under international law and the effects that advancements of surveillance technology have had over our evolutionary interpretation of UNCLOS. The paper's nuanced approach thus treats the EEZ surveillance
\end{abstract}

\footnotetext{
$\uparrow$ JSD Candidate at Yale Law School; Resident Fellow at the Information Society Project; Visiting Scholar at the Hebrew University Cyber Security Research Center; Robert L. Bernstein International Human Rights Fellow, Privacy International. This paper benefited from multiple presentations at the Yale Law School and the Information Society Project. The paper has additionally been work-shopped at the Salzburg Cutler Fellows in Law Program and at the Works-In-Progress Symposium of Yale Law's Graduate Programs Office. I wish to thank Michael Reisman, Ashley Deeks, Jenny Martinez, Eyal Benvenisti, Colin Agur, Graham Webster, Sofia Ranchordás, Tara Davenport, Rebecca Crootof, Jordan Blashek, Divya Musipally, and other attendees and commentators during the above events for their helpful feedback and pushback to previous drafts of this paper. I also wish to thank the members of the Washburn Law Journal Editorial Board for their invaluable work on making this piece better.
} 
problem as a microcosm through which to examine meta-issues concerning the function intelligence plays in our public world order.

\section{INTRODUCTION}

In the fifteenth century, if one were to speak of a naval intelligence operation, thoughts would probably have wandered to the Portuguese explorer Pêro da Covilhã. Traveling in disguise as an Arab honey merchant, da Covilhã provided King John II and his courtly advisers detailed and vivid reports of the intricate international trade routes between India and SubSaharan Africa. ${ }^{1}$ Moving to the eighteenth century, maritime intelligence collection remained intrinsically the same; examine, for instance, the tasks accomplished by Captain Caleb Brewster on board his Revenue Cutter "Active" during the American Revolutionary War. Brewster monitored the movement of enemy British Men-of-War off the coast of Long Island and relayed the information back to officials in New York. ${ }^{2}$ During World War I, naval surveillance officers continued to be predominantly occupied by traditional reconnaissance and monitoring missions. ${ }^{3}$ John Held, Jr., an agent of the U.S. Office of Naval Intelligence, offers a good example: Held served for fourteen months under the guise of an archeological researcher, while attempting to sketch potential hiding places for German submarines in Central America. ${ }^{4}$

1. For further discussion of the work of Pêro da Covilhã as a spy serving in the name of King John II, see PETER O. Koch, TO THE ENDS OF THE EARTH: THE AGE OF THE EUROPEAN EXPLORERS 6670 (McFarland 2003) ("Pêro da Covilhã was well suited for such an important and perilous assignment .... While in the King's service he participated quite admirably in a number of covert operations for the Crown, most notably as a secret agent at the Court of Spain's King Ferdinand and Queen Isabella. King John also sent him on intelligence gathering missions to the distant cities of Tlemcen and Fez in North Africa where, as well as learning the customs of the Arab people, he also managed, thanks to a gifted ear for language, to master the Arabic tongue .... King John II and his courtly advisers poured over the detailed reports supplied by Pêdro da Covilhã. His rich description of the local markets and vivid details of an intricate international network of trade occurring in the part of the world further strengthened Portugal's determination to find a route that would take them past the great barrier of Africa across the vast width of the Indian Ocean.").

2. See William H. Thiesen, War of 1812: Revenue Cutter Operations and the Core COAST GUARD MISSIONS 13-14 (2012), http://www.dtic.mil/get-tr-doc/pdf?AD=AD1024313 [https://perma.cc/Z44M-Z4VQ] ("With naval vessels cruising at sea and naval gunboats often stationed in port cities, revenue cutters became [efficient] maritime intelligence gathering tools. They did their best to monitor enemy naval movements, locate British privateers, and provide news regarding American merchantmen. Because of their speed and agility, the revenue cutters proved the most reliable source of this naval intelligence. Revenue cutter captains gathered and shared this information with customs collectors, local officials, newspapers and military personnel.... While the Active and General Greene proved the most notable intelligence gathering revenue cutters, the rest of the cutters also reported important military intelligence, such as numbers and positions of enemy ships, landing of troops, and provisioning of enemy vessels.").

3. See generally Christopher Ford \& DAVID Rosenberg, THE AdMIRALS’ AdVANTAGe: U.S. NAVY OPERATIONAL INTELLIGENCE IN WORLD WAR II AND THE COLD WAR (2005). It should be noted that World War I did introduce the potential of radio interception in advancing military goals. The British naval commanders relied on such interceptions in tackling the new naval threat presented by German submarines. This later formed the basis for the expansion in usage of High-Frequency Direction Finding ("HF/DF") during World War II. Id.

4. WyMAN H. PACKARD, A CENTURY OF U.S. NAVAl INTELLIGENCE 41 (1996). 
It was truly World War II and to a greater extent the Cold War that were the crucible in which maritime signal intelligence gathering ("SIGINT") and maritime electronic intelligence gathering ("ELINT") first began to take shape. ${ }^{5}$ This era saw a flood of advancements in the field of applied sciences, including: radar, sonar, and laser technologies; electrooptical, oceanographic, hydrographic, acoustic, geophysical, and geospatial sensing; satellite spot-beam and microwave relay traffic interception systems; airborne and ship-based maritime communication surveillance, and electronic warfare ("EW") capabilities; and more recently, longendurance reconnaissance Unmanned Aerial Vehicles ("UAV") and Unmanned Maritime Systems ("UMS"). These technologies helped reconceptualize and revolutionize maritime intelligence collection in both peacetime and wartime. ${ }^{6}$ Operations that once involved a risk to a State's diplomatic relations and to the lives of airmen and ground troops could now be performed in a covert manner and at a greater distance from both the target and the coastal State.

The ability to operate militarily from beyond the littoral and to collect new types and greater volumes of information introduced a series of evermore complex legal and policy considerations. ${ }^{7}$ Moreover, with the development of EW capabilities, States could now jam or even paralyze a coastal State's communication and defense systems, thus shifting away from "passive" intelligence gathering operations to "active" perpetration of electronic attacks from outside territorial bounds. ${ }^{8}$ As was noted by one

5. Judson Knight, Ships Designed for Intelligence Collection, ESPIONAGE INFORMATION: ENCYCLOPEDIA OF ESPIONAGE, INTELLIGENCE, AND SECURITY, http://www.faqs.org/espionage/SeSp/Ships-Designed-for-Intelligence-Collection.html [https://perma.cc/STS5-66CJ] ("The concept of using ships as modern intelligence-gathering platforms evolved, along with larger modern ideas of intelligence operations in general, from World War II. The Cold War saw the deployment, on both the Soviet and American sides, of ships tasked with gathering communications and electronic intelligence. Some of these were disguised as fishing vessels, a practice common on the Soviet side, while the United States favored vessels operating under the guise of research craft.").

6. For a complete review of technological advances in the field of maritime intelligence gathering, see Desmond Ball, Intelligence Collection Operations and EEZs: The Implications of New Technology, 28 MARINE POL'Y 67 (2004). See also H. Lawrence Clark, Technology Development for Ocean Sciences at NSF, in 50 YeARS OF OCEAN DisCOVERY: NATIONAL SCIENCE FOUNDATION 1950$2000128,128-32$ (2000).

7. See generally Stuart Kaye, Freedom of Navigation, Surveillance and Security: Legal Issues Surrounding the Collection of Intelligence from Beyond the Littoral, 24 AUSTL. Y.B. INT'L L. 93 (2005).

8. Moritaka Hayashi, Military and Intelligence Gathering Activities in the EEZ: Definition of Key Terms, 29 MARINE POL'Y 123, 126 (2005) (emphasis omitted) (noting that "the [United Nations] Charter and subsequent legal developments in the United Nations have not taken into account highly advanced technologies, in particular the latest electronic warfare (EW) capabilities which are becoming increasingly more intensive and intrusive. A crucial question is whether some of the EW-related activities conducted in or above the EEZ should be considered to be inconsistent with the Charter and thus the peaceful purposes clauses of the 1982 UNCLOS. Particularly relevant in this context are active signals intelligence (SIGINT) activities conducted from aircraft and ships, some of which are deliberately provocative, and intended to generate programmed responses. Other SIGINT activities intercept naval radar and emitters, thus enabling the location, identification, and tracking of surface ships as well as the planning and preparation of electronic or missile attacks against them. These activities appear to involve far greater interference with the communication and defense systems of the targeted coastal State than any traditional passive intelligence gathering activities conducted from outside 
commentator, these new technological advances in maritime espionage, while offering a great promise to navies, serve as a destabilizing force, further threatening to unravel the delicate fabric of international maritime security:

The recent developments with respect to SIGINT, [electronic-warfare] and cyber-warfare capabilities and activities in maritime areas are likely, on balance, to be destabilising in crisis situations and detrimental to regional security in general. SIGINT, ELINT and network-related collection activities are not only increasing, they are also likely to become more intrusive-and more important for the infringed party to take defensive measures against. ${ }^{9}$

Further clouding this worrisome picture of stability-thwarting technology is the "vague and ambiguous" legal framework governing surveillance activities within and above the Exclusive Economic Zone ("EEZ"). ${ }^{10}$ The regime of the EEZ is one of the greatest novelties of the 1982 United Nations Convention on the Law of the Sea ("UNCLOS"). ${ }^{11}$ Nonetheless this juridical innovation brought with it a "battle for control" between the rights of the coastal State and the maritime use claims of foreign States. As noted by Galdorisi and Kaufman:

Like the transformation of a river's fresh flowing water into that of the salty sea, the transition from territorial seas to high seas is not abrupt. There is no clear and bright line, but rather a region where the sea absorbs and dilutes the silty residue of sovereign ground, gradually replacing its fresh, muddy, provincial brown with salt and clear blue water freedom. Currents carrying elements of coastal State sovereignty and jurisdiction converge and combine in the EEZ with those containing freedoms of navigation and associated uses in favor of all States, swirling and twisting

national territory.").

9. Ball, supra note 6, at 78. See also Xue Guifang (Julia), Surveys and Research Activities in the EEZ: Issues and Prospects, in Military ACTIVITIES IN THE EEZ: A U.S.-ChINA DiAlogue ON SECURITY AND INTERNATIONAL LAW IN THE MARITIME COMMONS 89, 94 (Peter Dutton ed., 2010) (in the context of the parallel issue of Marine Scientific Research ("MSR"), Guifang similarly argues that "[a]long with the advancement of technology in recent decades, tremendous capabilities have been employed to collect large amounts of marine data using various instruments deployed from ships, such as balloons, profiling floats, moored and drifting buoys, remotely operated vehicles, and offshore or near-offshore fixed platforms. The data for MSR can also be collected by satellite or by equipment on civilian or military aircraft or ships. More and more research projects use remote-sensing technologies on platforms located outside the jurisdictional waters of coastal states. The coastal state can find attempting to distinguish among hydrographic surveys, military surveys, and MSR in its EEZ very frustrating. This state of affairs may eventually lead to a collapse of the present MSR regime in the EEZ.").

10. George V. Galdorisi \& Alan Kaufman, Military Activities in the Exclusive Economic Zone: Preventing Uncertainty and Defusing Conflict, 32 CAL. W. INT'L L. J. 253, 255 (2002); see also Boleslaw Adam Boczek, Peacetime Military Activities in the Exclusive Economic Zone of Third Countries, 19 OCEAN DEV. \& INT'L L. 445, 458 ("While it is true that the institution of the EEZ has become an established fact and rule of customary international law, codified in the U.N. Convention on the Law of the Sea of 1982, the precise scope of the rights of the coastal and other states in the zone still remains to be defined in the free interplay of the competing interests of the coastal Third World countries on the one hand and the maritime nations supporting the traditional freedoms of the sea on the other. The uncertainty is nowhere so striking as in the area of the military uses of the EEZ.").

11. United Nations Convention on the Law of the Sea, Dec. 10, 1982, 1833 U.N.T.S. 397 [hereinafter UNCLOS]. 
in sometimes competing directions. The EEZ is, in a juridical sense, brackish, murky and treacherous water; a 188 mile-wide band of turbulent ocean separating the territorial sea from the high seas in which competing desires for control and use meet, mix and merge. The EEZ is a zone of tension between coastal State control and maritime State use of the sea. The battle for control defines the exclusive economic zone. ${ }^{12}$

This "battle for control" is perhaps most heightened in the context of military activities and intelligence collection operations, conducted within and above a coastal State's EEZ. The delegations to the Third United Nations Conference on the Law of the Sea ("UNCLOS III") preferred "not to make any express statement about the problem of military uses in the exclusive economic zone," arguing against the appropriateness of the conference as a forum for such negotiations. ${ }^{13}$ The final wording of UNCLOS Part V thus intentionally left open the volatile question of peacetime naval maneuvers and reconnaissance missions within and above the zone. ${ }^{14}$

This has since resulted in a series of contentious security claims based

12. Galdorisi \& Kaufman, supra note 10 , at 257.

13. R.W.G. de Muralt, The Military Aspects of the U.N. Law of the Sea Convention, 32 NILR 78, 94 (1985); see also FranCisco ORREGO VICUÑA, The EXClusive ECONOMIC ZONE: REGIME AND LEGAL NATURE UNDER INTERNATIONAL LAW 108 (1989) (stressing that one of the most troubling elements of the work of the Third Conference on the Law of the Sea was the military use of the EEZ, arguing that: "Although the subject was discussed only occasionally and was never the object of formal negotiation, it was implicitly present behind many of the provisions on the exclusive economic zone that we have examined and in the interpretations that have been made since then. Although some countries promoted the formal discussion of the subject, it was never accepted by the maritime powers, since in their opinion this issue did not correspond to the Law of the Sea Conference but to special forums in the field of department and the like.... Whatever the answer may be, the maritime powers would hardly accept restrictions on their wartime military activities"); Robert Beckman \& Tara Davenport, The EEZ Regime: Reflections After 30 Years, in LOSI CONFERENCE PAPERS: SECURING THE OCEAN FOR THE NeXt Generation 2, 24-25 (Harry N. Scheiber \& Moon Sang Kwon, eds., 2012) https://www.law.berkeley.edu/files/Beckman-Davenport-final.pdf [https://perma.cc/GZP6-YYZJ] (attributing the vagueness of wording of UNCLOS Article 58 to the compromises reached during negotiations and noting that: "Military activities or uses in the EEZ were not explicitly mentioned during official negotiations, due to the belief of many States, including the US, that this would quickly derail any efforts for a convention. However, there was no doubt that preserving the traditional high seas freedom of military operations and activities in the EEZ was a high priority for the US . . . However, it is also fair to say that some coastal States such as Brazil persistently objected to this interpretation.").

14. Francesco Francioni, Peacetime Use of Force, Military Activities, and the New Law of the Sea, 18 CORNELL INT'L L. J. 203, 213-14 (“The Convention alone provides no easy answer to the question of how establishment of the EEZ may affect peaceful military activities by foreign navies. Rather, the Convention's provisions on the EEZ leave a large margin of ambiguity and uncertainty as to the nature, status, and scope of coastal states' rights within the zone. Such ambiguity is understandable in a legal instrument whose relevant provisions were drafted under the strain of opposing tendencies ..... Apart from spelling out freedom of navigation in the EEZ and in the upper adjacent air space, article 87 does not clarify which foreign naval military activities are lawful in the EEZ. Controversial activities include military maneuvers; weapons tests; the gathering of strategic information by intelligence ships or airplanes; launching, landing or taking on board aircraft or any other military equipment or device."); see also Alexander Skaridov, Military Activity in the EEZ, in FREEDOM OF SEAS, PASSAGE RIGHTS AND THE 1982 LAW OF THE SEA CONVENTION 249, 262 (Myron H. Nordquist et al. eds., 2009) ("'Uncertainty' is probably the best word to describe the status of 'military activity' in the modern Law of the Sea. The 1982 UNCLOS is not an appropriate instrument to resolve controversial issues, particularly, in regard to the EEZs and continental shelf claims. Because of this the most critical items like combat exercises, intelligence gathering, and hydrographic surveys very much depend on the coastal State's interests and regional ambitions."); Galdorisi \& Kaufman, supra note 10, at 269-73. 
on conflicting interpretations of the provisions of UNCLOS, ${ }^{15}$ as well as numerous maritime protests, confrontations, and incidents involving fishing and oil exploration vessels, coast guard and naval ships, and military aircraft. ${ }^{16}$ Perhaps most well-known of these were the string of SinoAmerican maritime incidents and confrontations in the South China Sea, ${ }^{17}$ including in particular the 2001 EP-3 and 2009 USNS Impeccable crises. ${ }^{18}$ Similar incidents, of lower gravity but equal volatility, persist to this day, a recent example being the intercept of a U.S. EP-3 surveillance aircraft over the East China Sea by Chinese fighter jets in July $2017 .{ }^{19}$

This fractious dispute has brought some commentators to argue that the controversy over intelligence collection within and above the EEZ will not be resolved inside the realm of the law. ${ }^{20}$ Others have claimed that

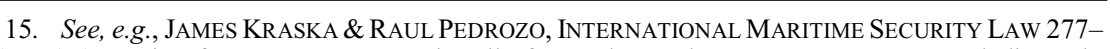
78 (2013) ("Moving from West to East, virtually from Al Barsah, Iraq, next to Iran, to Vladivostok, Russia, just 30 miles from North Korea, there is a 7000-mile unbroken line of States that purport to limit military activities in the EEZ that stretches from the Persian Gulf all the way to East Asia.... Worldwide there are 18 nations that claim a security interest in the Exclusive Economic Zone, typically by purporting to restrict foreign-flagged military activities. Among these nations, two are in South America (Brazil and Uruguay), two in Africa (Kenya and Cape Verde), one in the Middle East (Iran), and 13 are in Asia [Pakistan, India, Bangladesh, Myanmar, Thailand, Cambodia, Malaysia, Vietnam, China and North Korea, Maldives, Mauritius and Indonesia .... In addition, the seven nations that illegally claim territorial seas in excess of $12 \mathrm{~nm}$ include: Benin (200nm), Republic of Congo (200nm) Ecuador (200nm), Liberia (200nm), Peru (200nm), Somalia (200nm) and Togo (30nm) . . . And there are five nations that claim security jurisdiction in their $24 \mathrm{~nm}$ contiguous zone."); see also de Muralt, supra note 13 , at $94-95$.

16. See Mark J. Valencia, Military and Intelligence Gathering Activities in Exclusive Economic Zones: Consensus and Disagreement, Summary of the Bali Dialogue, 4-10 (June 27-28, 2002), www.eastwestcenter.org/sites/default/files/private/BaliDialogue.pdf [https://perma.cc/52NB-ZH38] [hereinafter Summary of the Bali Dialogue]; Raul (Pete) Pedrozo, Preserving Navigational Rights and Freedoms: The Right to Conduct Military Activities in China's Exclusive Economic Zone, 9 CHIN. J. INT'L L. 9, 12-18 (2010).

17. The dispute is most apparent in the Asia-Pacific region, in part for the fact that quite a number of overlapping 200nm EEZ claims persist there. Moreover, within the Asia-Pacific region there are a number of significant actors which "purport to regulate military activities in the EEZ in one form or another," namely: India, Malaysia, Burma, Indonesia, PRC, Bangladesh, the Maldives, Mauritius, and North Korea. See Raul (Pete) Pedrozo, Military Activities In and Over the Exclusive Economic Zone, in Freedom of Seas, Passage Rights and the 1982 LaW of the Sea Convention 235, 237 (Myron H. Nordquist et al. eds., 2009).

18. Andrew S. Erickson \& Emily de La Bruyere, China's RIMPAC Maritime-Surveillance Gambit, THE NATIONAL INTEREST (July 29, 2014), http://nationalinterest.org/feature/china\%E2\%80\%99srimpac-maritime-surveillance-gambit-10970 [https://perma.cc/2ZCP-Z77Z ]. Other incidents include China's interference with the USNS Bowditch in 2001, the USNS Victorious in 2009, and, more recently, China's dispatch of an Auxiliary General Intelligence vessel off the coast of Hawaii during its first appearance in the Rim of the Pacific Maritime exercises of July 2014. Id. For a summary of these incidents, see Ankit Panda, East China Sea: 2 Chinese Fighters Conduct 'Unsafe' Intercept of US EP3 Surveillance Aircraft, THE DIPLOMAT (July 25, 2017), http://thediplomat.com/2017/07/east-china-sea2-chinese-fighters-conduct-unsafe-intercept-of-us-ep-3-surveillance-aircraft/ [https://perma.cc/T2JPCW8D ]; see also infra notes 152-155 and accompanying text (describing more incidents of China's interference); see generally RONALD O'ROURKE, CONG. RESEARCH SERV., R42784, MARITIME TERRITORIAL AND EXCLUSIVE ECONOMIC ZONE (EEZ) DISPUTES INVOLVING CHINA: IsSUES FOR CONGRESS, 4-7 (2014).

19. See Panda, supra note 18. Two Chinese Air Force fighters conducted an intercept of a U.S. Navy EP-3 Aries surveillance aircraft over the East China Sea. The incident occurred eighty nauticalmiles off China's mainland. According to one report the two Chinese jets "came within 300 feet of the EP-3" and forced them to change course in mid-air. Id.

20. Alan M. Wachman, Playing by or Playing with the Rules of UNCLOS, in MILITARY ACTIVITIES IN THE EEZ: A U.S.-CHINA DIALOGUE ON SECURITY AND INTERNATIONAL LAW IN THE 
setting any legal restrictions, in an age of technological advancement, would prove "ineffective and irrelevant." 21 Nonetheless, States, scholars, and research institutes remain firm in their call for a legal compromise between currently existing permissive and prohibitive interpretive approaches to the UNCLOS debate. ${ }^{22}$

This paper seeks to respond to these calls for such compromise, by developing a new conciliatory legal model for intelligence gathering within and above the EEZ. In developing this model, the author rejects previous scholarly attempts to resolve the dispute by relying solely on traditional treaty interpretation approaches. Instead, the author examines the EEZ surveillance conundrum through a consideration of the specific function intelligence serves in our public world order. The paper is thus divided into three Sections.

The first Section presents the conflicting legal positions underlying the debate between currently existing prohibitive and permissive interpretive approaches to UNCLOS Article 58(1). ${ }^{23}$ At the heart of this debate lies the

MARITIME COMMONS 107, 108-11 (Peter Dutton ed., 2010) (noting that "[a] resolution of the EEZ issue is unlikely to emerge from a discussion of law, because the law is not really the problem. Sino-U.S. relations are strained because of the ways in which the strategic aims of Beijing and Washington collide and chafe against one another during a period of rapid transition of stature and perceived power .... For both American and Chinese strategists and statesmen, then, the controversy about what is allowable under UNCLOS is not a simple question of how best to interpret the convention but is the outgrowth of geostrategic competition under conditions of a security dilemma. Both defend their positions as matters of principle .... Fundamentally, each side deploys legal reasoning to justify actions it feels compelled to take for the enhancement of its security. As neither side is prepared to debase itself by relinquishing its pretense of equanimity - divulging how menaced the other makes it feel-each behaves as an aggrieved party, deprived of rights that it claims are plainly stated in UNCLOS, rights that it believes it could yet enjoy if only the other side would recognize the proper interpretation of the law. For both Americans and Chinese writing on this matter, fault rests squarely on the shoulders of the other nation. Neither is prepared to acknowledge or 'own' the means by which it exacerbates underlying suspicions by actions it takes.").

21. See Summary of the Bali Dialogue, supra note 16, at 18 ("Technology has dramatically changed the art of warfare and intelligence gathering. There have been vast improvements in the range and accuracy of both weaponry and intelligence collection so that, in the age of Aegis, satellites, aircraft carriers, missiles, and over-the-horizon weaponry and intelligence collection, extending restrictions in the EEZ is largely ineffective and irrelevant.").

22. See, e.g., Kaye, supra note 7, at 104-05 ("The gathering of intelligence from the sea and air raises difficult questions for the international community. The Law of the Sea Convention largely avoids issues surrounding military activities. This is both an indication of the tension surrounding these issues, and avoidance itself has created difficulties .... The international community should endeavour to clarify the rights and duties of states in the context of navigation and intelligence gathering, to avoid incidents such as that in the South China Sea occurring."); Galdorisi \& Kaufman, supra note 10, at 300 ("When all is said and done the salient fact remains that the EEZ is an important international area and that vast oceanic areas, that were once the high seas, are now included in the EEZ .... [T]he international community is left to make peaceful resolution of the contentious issues regarding military activities in the EEZ a matter of priority."); Summary of the Bali Dialogue, supra note 16, at 20-21 ("States have fundamental disagreement over whether military activities in the EEZ should have any limits .... The views on how to address these disagreements are disparate and wide-ranging... [S]ome believe that the situation is sufficiently urgent, complicated, and rife with misunderstanding that concerned states should be pro-active .... Clearly there is a need for greater communication and transparency within the region. Further dialogue and research is needed on the meaning of relevant Convention provisions.").

23. UNCLOS, supra note 11, art. 58(1) ("In the exclusive economic zone, all States, whether coastal or land-locked, enjoy, subject to the relevant provisions of this Convention, the freedoms referred to in article 87 of navigation and overflight and of the laying of submarine cables and pipelines, and 
long-established clash between the customary law of the sea principle of "freedom of navigation" 24 and the equally pertinent U.N. Charter principles of "sovereign equality," "territorial integrity," and "non-intervention." 25 The Section will examine the permissivist argument raised in favor of allowing intelligence collection in and above the EEZ of coastal States, its strongest proponent being the United States; followed by a review of the prohibitionist counter-arguments raised in favor of restricting such intelligence collection activities, done without the prior consent of the coastal States, the most vocal advocate of this approach being the People's Republic of China ("PRC"). As we shall see, both of these one-dimensional legal maxims seem more concerned with discrediting each other rather than illuminating political and legal solutions, thus setting the stage for an alternative broader analysis of the law and policy-considerations surrounding the issue.

The second Section attempts to offer such an analysis. This article turns to the question: To what extent, and under what circumstances, should surveillance in the EEZ qualify as "internationally lawful uses of the seas," 26 or as serving "peaceful purposes"? ${ }^{27}$ Stepping outside the wording of UNCLOS, the Section offers different lenses through which to understand the EEZ intelligence conundrum. The Section begins by examining the function intelligence performs in our public world order. The Section further reaffirms the right of a State to spy (the jus ad explorationem) as a derivative sovereign right under international law. Nonetheless, taking into account the modern expansion of States' surveillance capabilities as well as the proliferation of threats to maritime security, the Section tries to determine when the right to spy might be abused. The Section thus relies on the evolutionary interpretation of treaties and on the doctrine of abuse of rights with the aim of further elucidating policy considerations in this field.

Drawing on this review, the third and final Section presents a new legal model for determining the legitimacy of certain intelligence gathering activities within and above the zone. While accepting "freedom of

other internationally lawful uses of the sea related to these freedoms, such as those associated with the operation of ships, aircraft and submarine cables and pipelines, and compatible with the other provisions of this Convention.").

24. Id. art. $87(1)(\mathrm{a})$.

25. U.N. Charter art. 2(1), (4), (7); see also G.A. Res. 2625 (XXV), annex, Declaration on Principles of International Law Concerning Friendly Relations and Cooperation Among States (Oct. 24, 1970); G.A. Res. 2131 (XX), Declaration on the Inadmissibility of Intervention in the Domestic Affairs of States and the Protection of Their Independence and Sovereignty, art. 1, (Dec. 21, 1965); G.A. Res. $36 / 103$, annex, Declaration on the Inadmissibility of Intervention and Interference in the Internal Affairs of States, ๆ 2(II)(f) (Dec. 9, 1981).

26. UNCLOS, supra note 11 , art. 58(1).

27. Id. art. 88 ("The high seas shall be reserved for peaceful purposes."); see also id. art. 58(2) ("Articles 88 and 115 and other pertinent rules of international law apply to the exclusive economic zone in so far as they are not incompatible with this Part."). 
navigation" as an analytical premise, the Section, for reasons of ensuring minimum order, introduces a set of restraints ("necessity," "last resort," and "proportionality") on third States' unilateral covert intelligence gathering operations within the zone. The Section then concludes by looking at a number of recent real-life controversies, attempting to square them with the above-mentioned criteria.

\section{IN THE JAWS OF THE DRAGON-KINGS}

The mythology of ancient China tells the story of four great DragonKings: Ao Kuang, Ao Chin, Ao Jun, and Ao Shun. Each of the DragonKings controlled a different portion of the seas under the direction of the Tiān Gōng, the "Heavenly Duke," the Jade Emperor. The Dragon-Kings ruled over all aquatic life and were responsible for the distribution of the rains and waters by manipulating the clouds. They lived in gorgeous crystal and pearl palaces in the depths of the sea, where they were attended by crayfish, lobsters, and crabs as guards, and by scaly fish as servants. ${ }^{28}$ The Dragon-Kings were depicted in traditional Chinese folklore as ghastly beasts:

Fish are boiled by the blast of its breath, and roasted by the fiery exhalations of its body. When it rises to the surface the whole ocean surges, waterspouts foam, and typhoons rage. When it flies, wingless, through the air, the winds howl, torrents of rain descend, houses are unroofed, the firmament is filled with a din, and whatever lies along its route is swept away with a roar in the hurricane created by the speed of its passage. ${ }^{29}$

Missile submarines, aircraft carriers, amphibious assault ships, cruisers, and destroyers are the modern-day equivalent of the DragonKings. If this analogy holds true, this would seem to make the United States and the PRC - in command of the two most powerful navies in the world $^{30}$ - our modern-day Jade Emperors. This is why much of the debate concerning the lawfulness of military maneuvers and surveillance operations within and above a coastal State EEZ has circled around the conflicting views presented by these two maritime superpowers.

Since it first originated as a unilateral proclamation by the Presidents of Chile and Peru in 1947, ${ }^{31}$ the concept of the EEZ has been embroiled in a legal dispute. Within this newly developed sui generis belt of waters, ${ }^{32}$ questions arose as to the extent of the sovereign territorial rights of coastal

28. CARol Rose, Giants, Monsters, and Dragons: An EnCyClopedia of FolKLORE, LEGEND AND MYTH 21 (2001).

29. EDWARD T.C. WERNER, MYTHS AND LEGENDS OF CHINA 210 (1922).

30. See Alex Trost \& VAdim Kravetsky, 100 of the Most Powerful Navies in the World (2013).

31. Counter-memorial of the Government of Chile, Maritime Dispute (Peru v. Chile), 2014 I.C.J. Pleadings 3, at 50-62 (Mar. 9, 2010).

32. Galdorisi \& Kaufman, supra note 10, at 273, 275. 
States and how these would be properly balanced off against the maritime States' navigational rights and freedoms. ${ }^{33}$ The recognition by the International Court of Justice ("ICJ") of the concept of the EEZ as forming "part of modern international law," 34 and the later codification of this regime within the 1982 Law of the Sea Convention, did not diffuse this inherent tension.

Coastal States enjoy, within their EEZ, full sovereign rights "for the purpose of exploring and exploiting, conserving and managing the natural resources, whether living or non-living, of the waters superjacent to the seabed and of the seabed and its subsoil, and with regard to other activities for the economic exploitation and exploration of the zone." 35 Coastal States also have limited jurisdiction with regard to the establishment and use of artificial islands, installations, and structures; marine scientific research ("MSR"); and the protection and preservation of the marine environment, within the zone. ${ }^{36}$ This list, however, is not exhaustive, as UNCLOS Article $56(1)(c)$ confers upon the coastal State other rights as provided for elsewhere in the Convention. ${ }^{37}$

In this context, specific attention has been given to the security claims of the coastal States. During negotiations, efforts were made by China and the members of the G-77 "to broaden coastal State rights and jurisdiction in the EEZ" as to include security interests. ${ }^{38}$ As noted previously, the majority of the delegates to UNCLOS III were reluctant to address this matter expressly. ${ }^{39}$ The final wording of UNCLOS, therefore, did not directly grant specific authorities to the coastal State to prevent or otherwise control military activities by third States within and above its EEZ; ${ }^{40}$ however, neither did it reject such authority. Instead, it recognized in Article 58(1) that all States, including landlocked States, shall enjoy within the EEZ the high seas rights and freedoms "of navigation and overflight and of the laying of submarine cables and pipelines, and other internationally

33. For a review of the historical origins and developments of the concept of the EEZ and its influence on the question of its legal nature, see VICUÑA, supra note 13, at 3-16.

34. Continental Shelf (Tunis. v. Libya), 1982 I.C.J. 18, 100 (Feb. 24).

35. UNCLOS, supra note 11, art. 56(1)(a). In particular, the Convention notes the rights of the coastal State in the field of energy production "from the water, currents and winds." Id.

36. See UNCLOS, supra note 11, art. 56(1)(b).

37. Id. art. 56(1)(c). For a broader discussion on the problem of residual rights of coastal States, see VICUÑA, supra note 13, at 35-39.

38. Pedrozo, supra note 16, at 10; see also 2 UNITED NATIONS CONVENTION ON THE LAW OF THE SEA 1982: A COMMENTARY 558 (Nandan, Rosenne and Grandy eds., 1993).

39. See supra notes 13-14 and accompanying text; infra note 86 and accompanying text.

40. Natalie Klein, Maritime Security and the LaW OF the Sea 46-47 (2011). Klein acknowledges that the "[c] ]oastal states are not ... granted any specific authority over military activities in the EEZ ... [nor is there] power vested in the coastal state to respond to acts that prejudice its peace, good order, or security as is the case with the territorial sea". Id. Nonetheless, Klein concludes by saying that "[t]he right of a coastal state to prevent or control military activities that occur within its EEZ remains controversial." Id. 
lawful uses of the sea." 41

Stating the law in this fashion did not resolve the dispute but simply turned the problem on its head. Instead of looking at the rights of coastal States to prevent military and surveillance exercises in their EEZs, the language of UNCLOS now called for an examination of whether the flag States are allowed to conduct such activities as a derivative of their high seas freedoms. This in turn has led to the development of two contradictory interpretative approaches to UNCLOS Article 58(1): a permissive approach and a prohibitive approach, most strongly advocated by the United States and the PRC, respectively. As explained by one commentator: "For China and other coastal countries, what is not authorized in the Convention is not permitted; for the US and other maritime powers, what is not explicitly prohibited in the Convention is permitted." 42

Should the Dragon-Kings be allowed to stir up the seas, or should they be shackled to territorial cages? This Section will summarize and evaluate the persuasiveness of the two conflicting answers to this question, as advanced by our modern-day Jade Emperors. In supporting their reading of Article 58(1), permissivist and prohibitionist scholars have both relied heavily on traditional treaty interpretation models as codified in the Vienna Convention on the Law of Treaties. ${ }^{43}$ These scholars have thus put forward, in support of their arguments, an analysis of the ordinary meaning of UNCLOS Part V articles, the object and purpose of the Convention, its travaux preparatoires, and the prior and subsequent practice of States coupled with additional policy rationales. ${ }^{44}$ Reviewing the literature, it becomes evident that both groups of scholars hold the other's arguments in low esteem, and assign something approaching divine authority to their positions. $^{45}$ By directly contrasting the permissive and prohibitive

41. UNCLOS, supra note 11, art. 58(1) (emphasis added). Article 88 further reaffirmed that the EEZ, much like the high seas, shall be reserved for "peaceful purposes." Id. art. 88 (emphasis added).

42. Ji Guoxing, The Legality of the "Impeccable Incident," in 5 CHINA SEC. No. 2, 19, 22 (2009), https://www.files.ethz.ch/isn/117001/Issue14full.pdf [https://perma.cc/MT5C-2KPF]. This sentiment echoes the now well-recognized Lotus doctrine in international law. See S.S. Lotus (Fr. v. Turk.), Judgment, 1927 P.C.I.J (ser. A) No. 9, at 19 (Sept. 7) ("[International law leaves states] in this respect a wide measure of discretion which is only limited in certain cases by prohibitive rules; as regards other cases, every State remains free to adopt the principles which it regards as best and most suitable."). I address later in the paper the limits of relying on Lotus in resolving this dispute. See infra Section III.

43. Vienna Convention on the Law of Treaties arts. 31-32, May 23, 1969, 1155 U.N.T.S. 331.

44. See, e.g., Jonathan G. Odom, The True "Lies" of the Impeccable Incident: What Really Happened, Who Disregarded International Law, and Why Every Nation (Outside of China) Should be Concerned, 18 Mich. ST. J. INT'L L. 411, 437 (2010) ("With both nations staking their respective legal claim about this matter on the record ... it is critical to consider the development of this area of international law in several stages. First, this requires considering the history predating the UNCLOS. Then, it involves considering the negotiations between nations of the world which resulted in the final text of UNCLOS. Next, it warrants looking at the actual terminology of UNCLOS itself. Finally, it means examining the state practice of the overwhelming majority of nations after UNCLOS was concluded. Ultimately, considering these critical facets of the applicable law will highlight the law in its actual state - vice as what one nation might wish it to be.") (emphasis added).

45. See, e.g., Wachman, supra note 20, at 111 ("[I]n Beijing as in Washington, the focus is on what UNCLOS permits and why it is therefore obvious that the other side is in violation of clearly stated 
interpretative approaches, this Section will show, however, that no clear international legal rule reigns supreme. Indeed, following traditional treaty interpretation approaches to the EEZ surveillance legal conundrum only gets one so far, as the matter was intentionally left unresolved by the drafters of UNCLOS. This will in turn set the stage for a minimum-order based alternative inspection of the EEZ surveillance issue, in Section II of this paper, which draws guidance from a deeper review of both the impact of new technologies on the law of the EEZ and the function intelligence performs in public life.

\section{A. The Permissive Approach: Letting the Dragon-Kings Stir Up the Seas}

Shortly after the signing of UNCLOS, President Reagan proclaimed a U.S. 200-mile EEZ, ${ }^{46}$ which was accompanied by a statement on United States' ocean policies. The statement began by stressing the leadership role taken by the United States in "developing customary and conventional law of the sea" with the objective of establishing "a legal order that will, among other things, facilitate peaceful, international uses of the oceans." 47 For the United States, the matter of what such "peaceful international uses" might entail, in the context of the EEZ, was a rather simple one.

It was in fact the American representative, Ambassador Elliot Richardson, who introduced the language of "internationally lawful uses" into Article 58(1). The intention behind the inclusion of this phrase was to secure that the traditional high seas freedoms would remain "qualitatively and quantitatively the same" when applied within the zone. ${ }^{48}$ The view of

precepts .... [E]fforts by American and Chinese commentators to convince each other of views they proffer as unassailable have, thus far, failed. Indeed, Americans and Chinese advocates frequently "talk past" one another. Where the EEZ is concerned, statesmen, scholars, soldiers, and other commentators advance assertions that flow from premises that are simply not shared by nationals in the other state.").

46. Proclamation No. 5030, 3 C.F.R. 22, 23 (1983) (concluding that "[w]ithout prejudice to the sovereign rights and jurisdiction of the United States, the Exclusive Economic Zone remains an area beyond the territory and territorial sea of the United States in which all States enjoy the high seas freedoms of navigation, overflight, the laying of submarine cables and pipelines, and other internationally lawful uses of the sea").

47. Presidential Statement on United States Ocean Policies, 19 WeEKLy COMP. Pres. DoC. 383 (Mar. 10, 1983) (emphasis added). The statement then proceeded to announce that:

[T] he United States will exercise and assert its navigation and overflight rights and freedoms on a worldwide basis in a manner that is consistent with the balance of interests reflected in the [UNCLOS]. The United States will not, however, acquiesce in unilateral acts of other states designed to restrict the rights and freedoms of international community in navigation Id. and overflight and other related high seas uses.

48. Elliot L. Richardson, Power, Mobility, and the Law of the Sea, 58 ForEIGN AFFAIRS 902,916 (explaining further the meaning of "qualitative" and "quantitative" in this context: "they must be qualitatively the same in the sense that the nature and extent of the right is the same as the traditional high-seas freedoms; they must be quantitatively the same in the sense that the included uses of the sea must embrace a range no less complete-and allow for future uses no less inclusive-than traditional highseas freedoms"); see also Beckman \& Davenport, supra note 13, at 25 ("To the US, the intention behind 'other internationally lawful uses of the sea related to these freedoms such as those associated with the operation of ships,' was to preserve traditional high seas freedoms such as the freedom to conduct a large range of military activities."); Raul (Pete) Pedrozo, Coastal State Jurisdiction over Marine Data 
the American delegates was that "military operations, exercises and other related activities have always been regarded as internationally lawful uses of the sea." 49 Therefore, so long as Article 58(1) protected such internationally lawful uses, "the right to conduct such activities will continue to be enjoyed by all States in the exclusive economic zone." 50 This would inevitably include intelligence collection and other reconnaissance operations. Modern day challenges to this contention, however, have brought permissivist scholars to raise four interpretive claims in defense of their position, briefly summarized below.

\section{Permissivist Reading of Ordinary Meaning, Object, and Purpose}

Permissive interpreters of the EEZ surveillance question note the fact that "the very nature of the EEZ, as indicated by its name, is that coastal states have been granted powers in this ocean area in order to protect and utilize the natural resources of their marine environment for economic reasons, rather than for traditionally conceived security interests." 51 Or as another commentator neatly phrased it: "It's the economic zone, stupid." 52

These scholars endorse a functional conceptualization of the EEZ according to which the only cases of interference which the coastal State may potentially engage with (and presumably respond to) are those relating to its economic utilization of the zone. ${ }^{53}$ Examples of such interference

Collection in the Exclusive Economic Zone, in MILITARY ACTIVITIES IN THE EEZ: A U.S.-CHINA Dialogue on Security and INTERNATIONAL LAW IN THE Maritime COMmONS 23, 34 (Peter Dutton ed., 2010).

49. Official Records of the Third United Nations Conference on the Law of the Sea, Plenary Meetings, Vol. 17, 244, U.N. Doc. A/CONF.62/WS/37 and Add.1-2 (Dec. 10, 1982).

50. Id.

51. KLEIN, supra note 40, at 46; see also Galdorisi \& Kaufman, supra note 10, at 262 ("A clear theme had emerged. These coastal States did not purport to seek sovereignty for its own sake, for the sake of pure territorial expansion, or for defense of the nation from military threat. They rationalized their need for sovereignty as needed to protect and utilize the natural resources of their marine environment. There interests were economic and environmental in nature. It followed, therefore, that uses associated with the exercise of freedom of navigation, to the extent that they did not intrude upon or harm these interests, were not at issue. The control they claimed to seek was of a limited nature; so, the exclusion required could be limited to that necessary to pre-serve and protect the stated environmental and economic interests.").

52. Odom, supra note 44, at 439 (emphasis added); see also Andrew S. Williams, Aerial Reconnaissance by Military Aircraft in the Exclusive Economic Zone, in MILITARY ACTIVITIES IN THE EEZ: A U.S.-CHINA DIALOGUE ON SECURITY AND INTERNATIONAL LAW IN THE MARITIME COMMONS 49, 50 (Peter Dutton ed., 2010). ("[A]t a minimum, that foreign military activity in the EEZ may not unduly interfere with the rights and interests of the coastal state in the marine environment and its natural resources. Examples of military activities that would run afoul of this provision include weapons exercises that cause significant damage to a valuable resource being exploited by the coastal state, that deny access to traditional fishing grounds, or that create hazards to commercial fishing.").

53. Zhiguo Gao, China and the Law of the Sea, in FreEDOM OF SEAS, PASSAGE Rights AND THE 1982 LAW OF THE SEA CONVENTION 265, 292 (Myron H. Nordquist et al. eds., 2009) ("It seems that there is at least some agreement on the conduct of military and intelligence gathering activities, that is, the exercise of freedom of navigation and overflight in and above EEZs should not interfere with or endanger the rights of the coastal State to protect and manage its own resources and its environment, and should not be for the purpose of marine scientific research. And the exercise of such freedoms of navigation and overflight should not interfere with the rights of the coastal States with regard to their 
include illegal fishing, severe environmental pollution, or unauthorized ocean mapping for scientific purposes, when conducted by third States. ${ }^{54}$ Anything beyond these restrictive bounds would fall outside the coastal State's jurisdiction and authority. For permissivists, the EEZ was created to achieve the UNCLOS preamble goals of "just and equitable international economic order" and the "economic and social advancement of all people of the world." 55 Attempting to assign to the EEZ other preamble goals would be dishonest and ineffectual.

Furthermore, permissivists' holistic understanding of the zone is rooted in UNCLOS Article 87, which guarantees high seas freedoms. ${ }^{56}$ In this context, for permissivist scholars, coastal States lack authority or enforcement power over military activities, including surveillance and reconnaissance activities, as any other interpretation would infringe on these core protected freedoms. ${ }^{57}$ Similarly, any interpretative reading of

establishment and use of artificial islands, installations and structures in the EEZ."); Francioni, supra note 14, at 225 ("[W]henever military activities come into conflict with peaceful uses, the former must yield to the latter. This is true not only with respect to the EEZ, where economic activities fall within the sovereignty of the coastal state, but also with respect to the area beyond national jurisdiction, where eventual exploration and exploitation of seabed minerals may well give rise to a problem of competition between military activities and economic use of ocean space. A standard of preference for economic use is not only logically justified in view of the necessary localization of resource-related activities, but above all permits at least some legal effectiveness to be given to the 'peaceful use' clauses and to the ordinary meaning of their language. This is in accordance with article 31(1) of the Vienna Convention and with the general principle of effectiveness, or effet utile.").

54. VICUÑA, supra note 13 , at 114 ; KLEIN, supra note 40 , at 46 . Note however that this too serves an opening for debate. In this context China has argued that U.S. Navy sonar use in its EEZ potentially could harm marine mammals and disrupt fish stocks and should thus be restricted. Pedrozo claims that "there is no evidence that the Navy's sonar use, while applying [various mitigation and] protective measures, impacts either marine mammals or fish." Pedrozo, supra note 16, at 24. Pedrozo further refers to a 2008 U.S. Supreme Court decision which rejected similar contentions to those of China, raised by environmental groups, noting that:

One of the most important ways the Navy prepare for war is through integrated training

exercises at sea. These exercises include training in the use of modern sonar to detect and

track enemy submarines, something the Navy has done for the past 40 years ... President

Theodore Roosevelt explained that 'the only way in which a navy can ever be made efficient

is by practice at sea, under all conditions which would have to be met if war existed'

Id.; see also Winter v. Natural Res. Def. Council, 555 U.S. 7, 11, 33 (2008) ("We do not discount the importance of plaintiff's ecological, scientific, and recreational interests in marine mammals. Those interests, however, are plainly outweighed by the Navy's need to conduct realistic training exercises to ensure that it is able to neutralize the threat posed by enemy submarines") (citation omitted).

55. UNCLOS, supra note 11 , at pmbl.

56. Id. art. 87(1) ("The high seas are open to all States, whether coastal or land-locked. Freedom of the high seas is exercised under the conditions laid down by this Convention and by other rules of international law. It comprises, inter alia, both for coastal and land-locked States: (a) freedom of navigation; (b) freedom of overflight; (c) freedom to lay submarine cables and pipelines, subject to Part VI; (d) freedom to construct artificial islands and other installations permitted under international law, subject to Part VI; (e) freedom of fishing, subject to the conditions laid down in section 2; (f) freedom of scientific research, subject to Parts VI and XIII.").

57. See, e.g., Testimony of Deputy Assistant Secretary of Defense Robert Scher, Asian and Pacific Security Affairs, Office of the Secretary of Defense, before the Subcommittee on East Asian and Pacific Affairs, Senate Committee on Foreign Relations, United States Senate (July 15, 2009), reprinted in O'ROURKE, supra note 18, at 38-39 (“[W]e reject any nation's attempt to place limits on the exercise of high seas freedoms within an exclusive economic zones [sic] (EEZ). Customary international law, as reflected in articles 58 and 87 of the 1982 United Nations Convention on the Law of the Sea, guarantees to all nations the right to exercise within the EEZ, high seas freedoms of navigation and overflight, as well as the traditional uses of the ocean related to those freedoms. It has been the position 
EEZ-related UNCLOS articles will acquire its legitimacy only if it applies this functional understanding. Two specific issues should be discussed at greater length in light of the permissivists' functional approach: "marine scientific research" and the principle of "due regard."

\section{i. "Marine Scientific Research" within the EEZ}

UNCLOS Article 56(1)(b)(ii) grants the coastal State jurisdiction over all MSR activities taking place within the EEZ. Article 246 further clarifies that the coastal States, in the exercise of their jurisdiction, have the right "to regulate, authorize and conduct" MSR in the zone. ${ }^{58}$ Although third States may conduct MSR operations with the consent of the coastal State, ${ }^{59}$ that consent should generally be granted, so long as "normal circumstances" persist. ${ }^{60}$ While UNCLOS is moot as to the definition of an MSR, ${ }^{61}$ commentators have noted that the Convention does reference "survey activities" and "hydrographic surveys" seemingly in isolation from "scientific research."62 Permissivist scholars have thus sought to narrow the meaning of MSR, relying on this fact and on their functional interpretation of the EEZ discussed above. In accordance with their understanding, MSR would only cover "resource related" activities which could effectively trigger the coastal States' recognized economic interests, ${ }^{63}$ thus excluding from the definition of MSR such activities as:

of the United States since 1982 when the Convention was established, that the navigational rights and freedoms applicable within the EEZ are qualitatively and quantitatively the same as those rights and freedoms applicable on the high seas").

58. UNCLOS, supra note 11, art. 246(1); cf. id. art. 245 (granting the coastal State within its territorial waters "exclusive right to regulate, authorize and conduct" MSR (emphasis added)).

59. Id. art. 246(2).

60. Id. art. 246(3). In this context Article 246(4) makes clear that: "for the purposes of applying [Article 246(3)], normal circumstances may exist in spite of the absence of diplomatic relations between the coastal State and the researching State." Id. art. 246(4).

61. A definition of MSR is not provided by UNCLOS "because there was a consensus at the conference that the substantive provisions of the convention clearly establish the meaning intended, making a definition of the term unnecessary." Wu Jilu, The Concept of Marine Scientific Research, in MILITARY ACTIVITIES IN THE EEZ: A U.S.-ChINA DiALOGUE ON SECURITY AND INTERNATIONAL LAW IN THE MARITIME COMMONS 65, 69-70 (Peter Dutton ed., 2010). Nonetheless, two draft definitions were submitted during UNCLOS III, the first by The Working Group on Marine Scientific Research and Transfer of Technology, which defined MSR as: "any study and related experimental work, excluding industrial exploration and other activities aimed at the direct exploitation of marine resources, designed to increase mankind's scientific knowledge of the marine environment and conducted for peaceful purposes"; the second by Colombia, El Salvador, Mexico, and Nigeria, which defined MSR for the purposes of the Convention as: "any study and related experimental work conducted in the marine environment designed to increase mankind's knowledge thereof." Id. at 70 .

62. UNCLOS, supra note 11, art. 19(2) ("Passage of a foreign ship shall be considered to be prejudicial . . . in any of the following activities . . . (j) the carrying out of research or survey activities") (emphasis added); id. art. 21(1) ("The coastal State may adopt laws and regulations ... in respect of all or any of the following ... (g) marine scientific research and_hydrographic surveys") (emphasis added); $i d$. art. 40 ("During transit passage, foreign ships, including marine scientific research and hydrographic survey ships, may not carry out any research or survey activities without the prior authorization of the States bordering straits.") (emphasis added).

63. Moritaka Hayashi, Military Activities in the Exclusive Economic Zones of Foreign Coastal States, in The 1982 Law of the Sea Convention at 30: Successes, Challenges and New 
hydrographic surveys, ${ }^{64}$ military surveys and surveillance, ${ }^{65}$ collection of meteorological data, routine ocean observations, and activities related to submerged wrecks or objects of an archeological and historical nature. ${ }^{66}$

Moreover, despite the fact that the EEZ regime grants the coastal State jurisdiction over the protection of the marine environment, ${ }^{67}$ U.S. Navy officials have argued that environmental monitoring, such as the assessment of marine pollution, would also fall outside the limited scope of MSR, basing this interpretive move on a broad reading of third States' obligations under UNCLOS Article 194. ${ }^{68}$ Captain Pedrozo (U.S. Navy JAG, retired) further distinguishes between MSR and other marine data collection activities, clarifying that:

[T]he primary difference between MSR and military marine data collection and hydrographic surveys is how the data are used once they are collected. Although the means of data collection may be the same as or similar to that used in MSR, and though it may be difficult for the coastal state to differentiate between MSR and other data-collection activities, the information obtained during military marine data collection or a hydrographic survey is intended for use by the military or to promote safety of navigation, respectively.... While some of these data may have economic utility, even though they were not collected for that

AGENDAS 121, 123 (David Freestone ed., 2013). In this context, MSR would be generally defined as "those activities undertaken in the ocean and coastal waters to expand scientific knowledge of the marine environment and its processes." J. ASHLEY ROACH \& ROBERT W. SMITH, UNITED STATES ReSPONSES to EXCESSIVE MARITIME Claims 426 (2d ed., 1996). For Pedrozo, this would include "physical oceanography, marine chemistry and biology, scientific ocean drilling and coring, geological and geophysical research, and other activities with scientific purposes. The data collected are normally shared freely with the public and the scientific community." Pedrozo, supra note 48, at 28.

64. KLEIN, supra note 40, at 221-22 (defining Hydrographic Surveys as information relevant "for the making of navigational charts and the safety of navigation," including "determination of one or more of several classes of data in coastal or relatively shallow areas - depth of water, configuration and nature of the natural bottom, directions and force of currents, heights and times of tides and water stages, and hazards of navigation - for the production of nautical charts and similar products to support safety of navigation").

65. Id. at 222 (defining Military Surveys as "activities undertaken in the ocean and coastal waters involving marine data collection (whether or not classified) for military purposes, and can include oceanographic, marine geological, geophysical, chemical, biological and acoustic data. Equipment used can include fathometers, swath bottom mappers, side scan sonars, bottom grab and coring systems, current meters and profilers").

66. Pedrozo, supra note 48, at 27. In accordance with The Commander's Handbook on the Law of Naval Operations: "[a]lthough coastal nation consent must be obtained in order to conduct marine scientific research in its exclusive economic zone, the coastal nation cannot regulate hydrographic surveys or military surveys conducted beyond its territorial sea, nor can it require notification of such activities." U.S. Navy, U.S. Marine Corps \& U.S. Coast Guard, The Commander's Handbook on the Law of Naval Operations, 2-9 (2007), http://www.jag.navy.mil/documents/NWP_1-14M_ Commanders_Handbook.pdf [https://perma.cc/79DB-ACQS].

67. UNCLOS, supra note 11, art. 56(1)(b)(iii).

68. Pedrozo, supra note 48, at 27; UNCLOS, supra note 11, art. 194(1), (2) ("States shall take, individually or jointly as appropriate, all measures consistent with this Convention that are necessary to prevent, reduce and control pollution of the marine environment from any source, using for this purpose the best practicable means at their disposal and in accordance with their capabilities, and they shall endeavour to harmonize their policies in this connection."); id. art. 194(2) ("States shall take all measures necessary to ensure that activities under their jurisdiction or control are so conducted as not to cause damage by pollution to other States and their environment, and that pollution arising from incidents or activities under their jurisdiction or control does not spread beyond the areas where they exercise sovereign rights in accordance with this Convention."). 
purpose, military marine data collected by the U.S. armed forces in foreign EEZs are used exclusively for military purposes and to promote safety of navigation and are not shared with the general public. ${ }^{69}$

Indeed, even the G-77 countries recognized the difference between military marine data collection and MSR, at least during UNCLOS III negotiations. The developing countries proposed to include "military activity" as its own category in the set of criteria enumerated in Article 246(5) (which lists situations in which coastal States may, in their discretion, withhold consent to the conduct of an MSR). This proposal was eventually rejected, ${ }^{70}$ further justifying the exclusion of military and hydrographic surveys from MSR's definitional scope (and thus from the overall scope of a coastal State's jurisdiction).

\section{ii. "Due Regard" obligations within the EEZ}

Article 56(2) and Article 58(3) of UNCLOS set reciprocal obligations on both the coastal State and flag State to have "due regard" to the rights and duties of their counterpart State in the performance of their duties under the Convention. ${ }^{71}$ If the EEZ regime had brought with it a "battle for control," 72 these provisions were developed with the aim of striking a "balance of interests and rights" between conflicting tides within the zone. ${ }^{73}$ Nonetheless, the Convention provides very little as to the actual meaning of "due regard," so much so that there seems to be "no agreed specific criterion for States to follow in determining whether their activities have fulfilled the 'due regard' requirement."74

The United States has taken the position that "due regard" should be equated with "reasonable regard," as defined under the High Seas Convention, ${ }^{75}$ noting that there is "no substantive difference between the two terms."76 The United States has contended in the context of the High Seas that:

69. Pedrozo, supra note 48, at 28-29.

70. Muralt, supra note 13 , at 97.

71. UNCLOS, supra note 11, art. 56(2) ("In exercising its rights and performing its duties under this Convention in the exclusive economic zone, the coastal State shall have due regard to the rights and duties of other States and shall act in a manner compatible with the provisions of this Convention."); id. art. 58(3) ("In exercising their rights and performing their duties under this Convention in the exclusive economic zone, States shall have due regard to the rights and duties of the coastal State.").

72. See supra note 12 and accompanying text.

73. Hayashi, supra note 8 , at 132 .

74. Id.

75. Convention on the High Seas art. 2, Apr. 29, 1958, 13 U.S.T. 2312, 450 U.N.T.S. 11 ("The high seas being open to all nations, no State may validly purport to subject any part of them to its sovereignty. Freedom of the high seas is exercised under the conditions laid down by these articles and by the other rules of international law .... These freedoms, and others which are recognized by the general principles of international law, shall be exercised by all States with reasonable regard to the interests of other States in their exercise of the freedom of the high seas.").

76. Beckman \& Davenport, supra note 13, at 14 ("UNCLOS adopted the formulation of "due regard' in relation to competing uses in the high seas, the Area and the EEZ instead of 'reasonable regard' referred to in the Fisheries Jurisdiction case, but the differences are purely semantic.”). 
The "reasonable regard/due regard" standard requires any using State to be cognizant of the interests of others in using a high seas area, to balance those interests with its own, and to refrain from activities that unreasonably interfere with the exercise of other States' high seas freedoms in light of that balancing of interests. ${ }^{77}$

To define what would constitute an "unreasonable interference," permissivists rely on the ICJ's Corfu Channel Case, which they understand as setting "a strong precedent that maritime navigational freedoms cannot be interfered with, even to protect security interests." 78 Furthermore, one commentator has suggested that: "the fact that a particular coastal State may have a low threshold of anxiety regarding ships and aircrafts off its coast cannot diminish the rights of the flag state." "79 In other words, for American scholars, the application of the "due regard" standard entails the exclusion of any of the PRC's subjective concerns, or a consideration of China's particular "eggshell skull" mentality as a former colony, ${ }^{80}$ when it comes to threats to its territorial integrity. Due regard becomes a technical, objective, and unyielding analysis of "reasonableness" directly linked to the actual rights and duties of both parties.

This position was also reflected in the American response to the interception of the USNS Impeccable (T-AGOS-23). The interception was executed by five PRC vessels on March 8, 2009 in the South China Sea, approximately 75 -miles from the Chinese coastline. The Pentagon released the following statement the day after the events:

The unprofessional maneuvers by Chinese vessels violated the requirement under international law to operate with due regard for the rights and safety of other lawful users of the ocean. We expect Chinese ships to act responsibly and refrain from provocative activities that could lead to miscalculation or a collision at sea, endangering vessels and the lives of U.S. and Chinese mariners. ${ }^{81}$

For the United States, the kind of "harassment" pursued by China, including the dropping of pieces of wood in the Impeccable's path and forcing it to make an emergency stop, objectively constituted an

77. U.S. Dep't of State, Dispatch Supplement, Law of the Sea Convention: Letters of Transmittal and Submittal and Commentary, Vol. 6, Supplement no. 1, 17 (1995) (emphasis added) https://coast.noaa.gov/data/Documents/OceanLawSearch/U.S.\%20Dep't\%20of\%20State,\%20Dispatch \%20Supplement,\%20Law\%20of\%20the $\% 20$ Sea\%20Convention,\%20Letters\%20 of $\% 20$ Transmittal $\%$ 20and\%20Submittal\%20and\%20Commentary\%20(Feb.\%201995).pdf [https://perma.cc/7BA2-LT5P].

78. Jon M. Van Dyke, Military Exclusion and Warning Zones on the High Seas, 15 MARINE POL'Y 147,168 (1991).

79. Elliot L. Richardson, Law of the Sea: Navigation and Other Traditional National Security Considerations, 19 SAN. DIEGO L. REV. 553, 574 (1982).

80. See Lyle J. Goldstein, Meeting China Halfway: How to Defuse the Emerging USCHINA RIVALRY 287 (2015) (“[T]his sensitivity should not be at all surprising, given China's experience with 'gunboat diplomacy', with coastal blockades after 1949, and with the fact that Hainan Island is the site of SSBN testing and future basing.").

81. RAW DATA: Pentagon Statement on Chinese Incident with U.S. Navy, Fox NEws (Mar. 9, 2009), http://www.foxnews.com/politics/2009/03/09/raw-data-pentagon-statement-chinese-incidentnavy/ [https://perma.cc/XY98-W3D4]. 
unreasonable interference that falls outside the ambit of PRC's obligations under the "due regard" requirement. ${ }^{82}$

\section{Permissivist Narrative of the Treaty Negotiations}

Commander Jonathan Odom of the U.S. Navy JAG summarizes the United States' position as to what actually unfolded at the UNCLOS III negotiations:

The nations at the bargaining table developed and refined a modification to the legal division of the oceans of the world which would become known as the exclusive economic zone. The purpose of this modification was clear: to accommodate those coastal states desiring to preserve their economic rights in the waters off their respective coasts. For activities which had no bearing on these economic rights, the nations at the bargaining table agreed to preserve the otherwise preexisting regime of high seas freedoms beyond the territorial seas of coastal states. The concept of an exclusive economic zone was not intended to reserve any rights for coastal states other than the economic rights of the coastal state in those waters, as well as a narrow slice of associated jurisdiction for specific purposes, such as protection of the environment from major damage. In fact, a handful of nations that attempted to insert a reference to the coastal state's security interests in the "due regard" clause of the exclusive economic zone articles were roundly defeated during the negotiations. ${ }^{83}$

This depiction of the negotiations is slightly misconstrued. As was already discussed above, the matter of military and electronic reconnaissance activities within the zone, was intentionally left out by the maritime superpowers during UNCLOS III. ${ }^{84}$ The United States was in fact the one who led the charge against any deliberation on the matter, its official delegate noting that:

The United States had consistently held that the conduct of military activities for peaceful purposes was in full accord with the Charter of the United Nations and with the principles of international law. Any specific limitation on military activities would require the negotiation of detailed arms control agreement. The Conference was not charged with such a purpose and was not prepared for such negotiations. Any attempt to turn the Conference's attention to such a complex task would quickly bring to

82. Bureau of East Asian and Pacific Affairs, Hearing Before East Asian and Pacific Affairs Subcomm. of the S. Foreign Relations Comm., 111th Cong. (2009) (Statement of Scot Marciel, Deputy Assistant Secretary), reprinted in O'ROURKE, supra note 18, at 27 ("In March 2009, the survey ship USNS Impeccable was conducting routine operations, consistent with international law, in international waters in the South China Sea. Actions taken by Chinese fishing vessels to harass the Impeccable put ships of both sides at risk, interfered with freedom of navigation, and were inconsistent with the obligation for ships at sea to show due regard for the safety of other ships. We immediately protested those actions to the Chinese government, and urged that our differences be resolved through established mechanisms for dialogue - not through ship-to-ship confrontations that put sailors and vessels at risk.") (emphasis added).

83. Odom, supra note 44, at 438.

84. See supra notes $13-14$ and accompanying text. 
an end current effort to negotiate a law of the sea convention. ${ }^{85}$

Nonetheless, according to the permissivist narrative, UNCLOS III hermetically settled the dispute regarding military activities within the zone, to the detriment of those few coastal States who sought broader jurisdiction. American commentators claim a near-unanimous resolve that existed during UNCLOS III to reject the attempts to "territorialize" the EEZ by incorporating the "security interests" of coastal States or limiting the navigational and overflight freedoms of third States. ${ }^{86}$ In this context, they refer to a number of countries, namely Germany, Italy, the United Kingdom, and the Netherlands, which have issued specific statements against potential "territorialization" of the zone upon ratification of UNCLOS. ${ }^{87}$

\section{Permissivist Understanding of State Practice}

This near-unanimity is also reflected, as permissivists contend, by State practice, both preceding and following the adoption of UNCLOS. As one commentator suggests: "[ $\mathrm{t}]$ he overwhelming majority of nations during the past three decades reflect that coastal States lack the authority to restrict foreign military activities within their respective EEZs." 88 Similarly, in the context of the airspace above the EEZ, commentators note that: "[s]ince the advent of aviation more than 100 years ago, military aircrafts have flown countless missions beyond national airspace, to include intelligence collection missions and military exercises along the outer limits of the territorial sea." 89

Permissivists thus claim that aerial, surface, and subsurface surveillance activities, conducted from beyond the territorial waters of another State, form part of an internationally accepted "routine." 90 The

85. 5 UNCLOS III O.R. (67th plenary $\mathrm{mtg}$.), $\uparrow 81$.

86. Pedrozo, supra note 48, at 24 ("[E]arly efforts by a handful of developing nations, like China, El Salvador, and Peru, to 'territorialize' the EEZ in order to broaden coastal-state authority in the new zone to include residual competences and rights (such as security interests) in [A]rticle 56 were rejected by the majority of the delegations at [UNCLOS III].").

87. Peter A. Dutton, Caelum Liberam: Air Defense Identification Zones Outside Sovereign Airspace 103(4) AM. J. INT'L L. 691, 697-698 (2009) (“"[U]pon ratification of the Convention, Germany specifically stated that 'the notion of a 200-mile zone of general rights of sovereignty and jurisdiction of the coastal State cannot be sustained either in general international law or under the relevant provisions of the Convention.' Likewise, the Italian declaration upon signature specified that the coastal state does not enjoy residual rights in the EEZ and has no authority under the Convention to require permission or notice of foreign military exercises or maneuvers in the EEZ. The Netherlands and the United Kingdom made similar statements.”).

88. Odom, supra note 44, at 440.

89. KRASKA \& PEDROZO, supra note 15, at 292.

90. Pedrozo, supra note 48, at 30 ("During the height of the Cold War, it was not uncommon for U.S. and NATO ships departing port to be met by a Soviet surveillance ship (AGI) at the outer edge of the territorial sea. Such activities were acceptable so long as the Soviet AGIs complied with their obligations under the 1972 International Regulations for Preventing Collisions at Sea (COLREGS) and the U.S.-USSR Prevention of Incidents on and over the High Seas agreement (INCSEA). The United States and its NATO allies responded to these activities with great tolerance. For example, in February 1974 a Soviet reconnaissance aircraft that was conducting a surveillance mission off the coast of Alaska ran low on fuel and had to make an emergency landing at Gambell Airfield in Alaska. The crew 
origins of this practice can be traced back to the Cold War, as suggested by Professor Lissitzyn:

Despite the tensions associated with the Cold War and similar political conflicts, states have generally refrained from claiming the legal right to interfere with foreign warships or aircraft outside their territorial seas or territorial airspace, even there were grounds for believing that the ships or aircraft were engaged in electronic reconnaissance in close proximity to the territory of the coastal state. ${ }^{91}$

More recent practice also seems to denote acceptance of such surveillance operations. Consider, for example, the July 2007 Norwegian interception of the Russian Tupolev-95 (“Tu-95") reconnaissance vessels above its EEZ; the August 2007 Canadian interception of Russian air jets just outside its aerial airspace near Newfoundland; or the September 2009 U.K. Royal Air Force interception of eight Russian Tu-95s off its northern coast. While in all three scenarios coastal States demanded explanations from Russia, they all seemed to accept Putin's response that "Russia's reconnaissance patrols are flown to protect shipping lanes and other vital Russian interests," and that such patrols are done in accordance with international law, over neutral waters, and without violating the territorial borders of other States. ${ }^{92}$

Moreover, some commentators have pointed out the fact that even the PRC itself has engaged in surveillance activities within other coastal States' EEZs. Pedrozo lists dozens of Chinese incursions within foreign EEZs throughout the Asia-Pacific between 2003 and 2009. ${ }^{93}$ More recently, a few minor controversies erupted following China's decision to dispatch

remained overnight and was provided space heaters and food by the American personnel. The plane was refueled the next day and allowed to depart without further incident. Similarly, in March 1994 a Russian surveillance aircraft monitoring a NATO antisubmarine warfare exercise ran low on fuel and made an emergency landing at Thule Air Base in Greenland. Again, the crew was fed and the aircraft was refueled and allowed to depart without further delay. In short, reconnaissance and surveillance activities at sea and in the air beyond the twelve-mile limit are nothing new and are well understood.").

91. Oliver J. Lissitzyn, Electronic Reconnaissance from the High Seas and International Law, 61 U.S. NAVAL WAR COLL. INT'L. L. STUDIES 563, 566 (1979); see also Dutton, supra note 87, at 701-02.

92. Dutton, supra note 87 at $702-03$.

93. Pedrozo, supra note 48, at 30-32; cf. Zhang Haiwen, Is it Safeguarding the Freedom of Navigation or Maritime Hegemony of the United States? —Comments on Raul (Pete) Pedrozo's Article on Military Activities in the EEZ, 9 CHIN. J. INT'L L. 31, 40 (2010) ("Pedrozo's Article lists a large number of disputes between China and Japan as examples to illustrate that, like the United States, Chinese military vessels also conducted military survey and intelligence activities in the EEZs of other countries ... there is an obvious cognitive error in the basic facts. For example, in the list of cases . . . some cases occurred in the so-called 'Japan's EEZ south-southwest of the Oki-no-Tori Shima' or 'in the vicinity of Okinotia.' For these cases, Pedrozo conveniently neglects a well-known fact, that is, a dispute over the Oki-no-Tori Shima between Japan on one side and China and the Republic of Korea on the other.... China neither needs to submit any application to Japan nor needs its approval. It is obviously wrong for Pedrozo to simply equate the controversy on Oki-no-Tori Shima between China and Japan with that between China and the United States triggered by the United States military activities in Chinese EEZ. Secondly, China and Japan have various kinds of maritime disputes, such as those regarding the sovereignty over Diaoyu Islands and delimitation of the EEZ and continental shelf in the East China Sea. Consequently, there is a dispute regarding jurisdiction over the activities in the disputed EEZ. Thus, according to the Chinese position, China does not need to obtain permission from Japan for Chinese vessels to enter into the EEZ claimed by itself to conduct marine data collection."). 
Auxiliary General Intelligence vessels to monitor western maritime exercises. The first incident occurred in an area off the coast of Hawaii during the Rim of the Pacific Maritime Exercises of July 2014, and the second occurred off the Queensland coast in the vicinity of the Talisman Sabre defense exercises. ${ }^{94}$ Commentators have suggested this reflects a double standard on the part of China, and argue the Chinese have a choice "between breathtaking (and unsustainable) hypocrisy and accepting that China's attitude to intelligence gathering in its own Exclusive Economic Zone must change."95 Perhaps China's recent engagement with EEZ surveillance is reflective of an evolution in policy, similar to the one taken by the Soviets in the 1960s. In the wake of the U2 spy planes incident, the Soviets were quick to rely on international law to argue that surveillance in their territorial airspace violated their sovereignty and international law. Over time, however, and with the advancement of the Soviets' own spying capabilities, the Soviets reverted back from this line of legal argumentation. This was codified in the signing of the Strategic Arms Limitation Talks ("SALT I"), in which the United States and the U.S.S.R. put into writing their consent to spying on each other in the monitoring of strategic arms control. ${ }^{96}$

For permissivists, any acceptance of the Chinese legal position would result in detrimental consequences. Given that EEZs encompass nearly $40 \%$ of the world's oceans, limiting freedom of navigation within foreign States' zones would deny military ships and aircraft access to several bodies of water:

[A]ll of the South China Sea, the Yellow Sea, the East China Sea, the Sea of Japan, the Philippine Sea, the Sea of Okhotsk, the Caribbean Sea, the North Sea, the Baltic Sea, the Mediterranean Sea, the Gulf of Aden, the Red Sea, the Persian Gulf, most of Oceania, and large swathes of the Indian Ocean. Such a result was clearly not envisioned during [UNCLOS III] and would never have been accepted by the maritime powers. ${ }^{97}$

\section{B. The Prohibitive Approach: Shackling the Dragon-Kings to Sovereign Cages}

The determined struggle for 200-nautical-mile maritime rights initiated

94. See, e.g., Erickson \& de La Bruyere, supra note 18.

95. See, e.g., James Goldrick, China's Intelligence Gathering at Sea: Some Implications, THE INTERPRETER (July 24, 2017), https://www.lowyinstitute.org/the-interpreter/china-s-intelligencegathering-sea-some-implications [https://perma.cc/K82P-69DR]. See also Panda, supra note 18 ("If Washington and its partners want to preserve the legal norm of freedom of navigation, however, they cannot begrudge the PLAN's activities. Instead, when Beijing protests similar activities within its own EEZ in the South and East China Seas, there will be a clearer double standard that can be highlighted.").

96. See generally Note, Legal Aspects of Reconnaissance in Airspace and Outerspace, 61 Columbia L. ReV. 1074 (1961).

97. Pedrozo, supra note 48, at 29. For a map highlighting the world's EEZ claims, see MAJ Chuah Meng Soon, Restrictions on Foreign Military Activities in the Exclusive Economic Zone: Major Powers' 'Lawfare', 42 J. SINGAPORE ARMED FORCES 12, 19 (2016). 
by Latin American Countries has won increasing support among the numerous small and medium-sized countries .... [These countries] are waging a gigantic and vigorous struggle against the maritime hegemony of the superpowers. With a view to seeking hegemony on the seas and oceans, the superpowers are trying in vain to preserve the outdated law of the sea and are doing their utmost to restrict the territorial sea and scope of jurisdiction of all countries .... They reflect the reality of the time when seas and oceans were controlled by colonialism and imperialism .... As to the assertion that the larger the territorial sea and the zones of jurisdiction, the smaller the open sea, the question must be asked: What is the open sea? The so-called open sea has in fact always been the "private sea" of a few strong naval powers. The numerous small and medium-sized countries have now stood up; they constitute the majority and demand a change in the so-called law of the sea, which is advantageous only to the imperialists. What fault can one find with this? ${ }^{98}$

In this decisive fashion, Chiao Kuan-hua, former PRC Minister of Foreign Affairs, addressed the 28th Session of the United Nations General Assembly a mere ten months after the signing of UNCLOS. His harsh words of rebuke were punctiliously selected, reflecting China's dismay at what it considered the hypocrisy of the maritime powers. From China's viewpoint, the superpowers were masquerading themselves as the custodians of high seas freedoms, while their true motivations were to preserve their domination over "the Mediterranean, the Persian Gulf, the Indian Ocean, the Caribbean, the Pacific and [the] Atlantic Ocean" and to extend "their rivalry in setting up bases and plundering the fishing and seabed resources there." 99 Kuan-hua was determined to pierce this veil. After being excluded from participation in the first and second conferences on the law of the sea, the PRC used the EEZ debate during UNCLOS III to emerge as a new leader for the developing world and a protector of coastal States' sovereign rights. While the PRC has since risen to the level of a maritime Jade Emperor, the mentality of colonialist victimhood, which was prevalent in the words advanced by Kuan-hua in 1973, still reflects modern-day Chinese dogmatic positions relating to the law of the sea. ${ }^{100}$

98. Chiao Kuan-hua, Chairman, Delegation of the People's Republic of China, Plenary Meeting of the 28th Session of the U.N. General Assembly, (1973),

http://www.bannedthought.net/China/MaoEra/UN/Speech-ChiaoKuan-hua-UN-GeneralAssembly1973.pdf [https://perma.cc/WAH4-H2C2].

99. Id.

100. Wachman, supra note 20, at 111 ("Chinese advocates have adopted the perspective with respect to the EEZ that the PRC has taken in other international controversies involving powerful states. The PRC assumes the mantle of the underprivileged developing state confronting harassment from the far stronger, developed state .... The PRC position is rife with implications of American hegemony reflecting, consciously or not, the well-trod narrative of China's sufferings at the hands of Western imperialism."); Haiwen, supra note 93, at 45 ("In the light of its strategic interests in maintaining global hegemony, any one of the military activities of the United States, including combat operations, of course, would be for 'peaceful purposes'! Has the United States ever considered or cared to some extent about how other countries in the world look at the hegemonic practices of the United States? Considering the current status of 'monopole dominance' of the United States in international politics, it is obvious that the United States has no need to take into account all of this."). There are certainly actors within the 
This historical imperial narrative is further enforced by China's topographical reality. As one commentator suggests, the two most significant physical features of China's geography, the length of its coastline (tenth longest coastline in the world) and the size of its continental shelf (seventh largest in the world), "naturally led China to adopt a position favoring extensive coastal State jurisdiction" during and following UNCLOS III negotiations. ${ }^{101}$

After ratifying UNCLOS in 1996, the PRC promulgated more than thirty laws and regulations "covering the basic marine legal system, mineral resources, fishing, environmental protection and marine scientific research among others." 102 Most pertinent to this analysis is the 1998 Law of the People's Republic of China on the EEZ and the Continental Shelf. ${ }^{103}$ The legislation emphasized the restrictions on third States' activities within the zone and assigned extensive authorities to the PRC in this context. Thus for example, while recognizing third States' freedom of navigation, over-flight, and other lawful uses within the zone, the EEZ law subjected these freedoms to "international laws and the laws and regulations of the People's Republic of China."104 Furthermore, the PRC reserved the right, in the exercise of its sovereignty within the zone, to "take necessary measures against violations of [PRC] laws and regulations in the exclusive economic zone ... and [to] exercise the right of hot pursuit;" such measures may include: "boarding, inspection, arrest, detention, and judicial processes, as may be necessary to ensure compliance."105 Phrasing the law in this manner manifestly distinguished the high seas freedom of navigation and over-flight from its narrower, more constrained, and subjected-to-coastalState-supervision sister, the freedom of navigation and over-flight within the sui generis waters of the EEZ. ${ }^{106}$ This distinction stands at the heart of

United States political scene who recognize this hegemonic power and base their UNCLOS interpretation in accordance with it. See, e.g., SCOTT G. BERGERSON, THE NATIONAL INTERESTS AND THE LAW OF THE SEA 17 (2009), http://www.cfr.org/oceans/national-interest-law-sea/p19156 [https://perma.cc/S5DR-JBMF] ("Opponents of the [UNCLOS] convention argue that there is no need to join the treaty because, with the world's hegemonic navy, the United States can treat the parts of the convention it likes as customary international law, following the convention's guidelines when it suits American interests and pursuing a unilateral course of action when it does not.").

101. Gao, supra note 53, at 272 .

102. Guoxing, supra note 42 , at 21 .

103. Law of the People's Republic of China on the Exclusive Economic Zone and the Continental Shelf (June 26, 1998), translated and reprinted in PARK HEE KWON, THE LAW OF THE SEA AND NORTHEAST ASIA: A CHALLENGE FOR COOPERATION 152-55 (2000).

104. Id. art. 11 ("All states, subject to international laws and the laws and regulations of the People's Republic of China, enjoy the freedoms of navigation and over-flight in its exclusive economic zone and of the laying of submarine cables and pipelines, and other lawful uses of the sea related to these freedoms in the exclusive economic zone and on the continental shelf of the People's Republic of China.").

105. Id. art. 12.

106. Guoxing, supra note 42, at 20-21 ("At present the United States regards the freedom of navigation in exclusive economic zones as equal to the freedom of navigation on high seas; but this is in conflict with the UNCLOS. Although the Convention grants freedom of navigation in the EEZ, such freedom is subject to the resource-related and environment-related laws and regulations of the coastal state. According to Article 58, in the exclusive economic zone, all States enjoy the freedoms of 
prohibitionists' responses to the permissivists' claims discussed above.

\section{Prohibitive Reading of Ordinary Meaning, Object, and Purpose}

While some prohibitionists take an extreme view, which equates "peaceful purposes" with demilitarization of the EEZ, 107 this is not the typical approach. Prohibitionists accept that all vessels, including military vessels, enjoy the freedom of navigation within and above the EEZ. ${ }^{108}$ The debate concerns, however, what that freedom entails today in a postUNCLOS world. As noted by one commentator:

[T] he Law of the Sea Convention formulated and agreed on a myriad of maritime zones .... In my mind it would be very difficult now to say that the freedom of the seas is still as before. I would even say that the freedom of the sea has become a highly regulated sea. From all sides and all kinds of views there is highly regulated use ... it is not as free as it was anymore. ${ }^{109}$

Prohibitionists cite the balancing limitations on the freedom of navigation in the EEZ, namely "lawful use" and "peaceful purposes," and expand them as far as legally possible. In this context, prohibitionists argue that the collection of military intelligence "openly encroach[es] on the national security and peaceful order" of the coastal State and should thus constitute a threat of force against territorial integrity in violation of U.N. Charter Article 2(4). ${ }^{110}$

Prohibitionists further stress the fact that UNCLOS was developed, in part, to allow the "strengthening of peace, security, cooperation and friendly relations among all nations in conformity with the principles of justice." 111 Considering this, Chinese prohibitionists raise the question of whether letting the United States fly more than "400 reconnaissance missions per

navigation, overflight, the laying of submarine cables and pipelines, but when exercising their rights, 'States shall have due regard to the rights and duties of the coastal State and shall comply with the laws and regulations adopted by the coastal State.' Thus, the United States enjoys the freedom of overflight and navigation in China's EEZ, but such freedom is not unrestricted, and US aircraft and vessels must observe the relevant Chinese laws.").

107. Li Guang-Yi, Legal Problem of Military Use in Exclusive Economic Zone, 2 J. OF XI'AN POL. 54,57 (2005) (suggesting that "the substantial spirit of the 'for peaceful purposes only' principle is complete demilitarization"). This approach attempts to tie the EEZ by analogy to other regimes in which demilitarization was adopted, or at least attempted, namely the regimes governing the Antarctic and the outer space and moon. See Francioni, supra note 14, at 222.

108. Haiwen, supra note 93, at 47 ("[A]lthough China opposes engaging in military activities in its EEZ without its consent, this is not directly equal to "military ships and aircraft of all nations would be denied access to all of the South China Sea, Yellow Sea, East China Sea, Sea of Japan, Philippine Sea...' which is mentioned by Pedrozo. That all vessels of all countries enjoy the freedom of navigation in its EEZ is a generally accepted rule and legal regime under the Convention. China never attempts to challenge this rule.").

109. Hasjim Djalal, Remarks on the Concept of "Freedom of Navigation", in FreEDOM OF SEAS, Passage Rights AND THE 1982 LAW OF THE SEA CONVENTION 65, 69-70 (Myron H. Nordquist et al. eds., 2009).

110. Guoxing, supra note 42 , at 20-22.

111. UNCLOS, supra note 11 , at pmbl. 
year around China, an average of over one per day," 112 is a political reality that sits well with the original goals and purposes of UNCLOS. This type of narrowing of maritime States' freedoms is also reflected in the prohibitionists' interpretation of the terms "MSR" and "due regard," as defined under UNCLOS.

\section{i. "Marine Scientific Research" within the EEZ}

As a starting point, prohibitionists reject any categorization of specific types of marine data collection activities, such as hydrographic, military, and research surveys. ${ }^{113}$ Although elsewhere in UNCLOS some of these activities are indeed mentioned separately, within the EEZ regime of UNCLOS Part V, ${ }^{114}$ survey activities are not distinguished by type, and therefore, they argue, should all be governed by the jurisdiction of the coastal State. ${ }^{115}$ This convergence in the legal understanding of these activities is also justified for practical reasons, as there is simply no way to draw sharp distinctions between these activities from a technical point of view. ${ }^{116}$ Dr. Bateman, formerly with the Australian Royal Navy, has for example concluded that: "marine scientific research, hydrographic surveying and military surveys all overlap to some extent. Some so-called military surveys, particularly military oceanographic research, are virtually the same as marine scientific research." 117 He also stated elsewhere that: "hydrographic surveying and marine scientific research are both similar and relatively recent innovations. Furthermore, technological developments with marine scientific research equipment in recent decades have made this similarity even more the case than it may have been at the time of UNCLOS

112. Ji Guoxing, Rough Waters in the South China Sea: Navigation Issues and Confidence-Building Measures, 53 ASIA PAC. ISSUES 1, 4 (2001).

113. Haiwen, supra note 93, at 42 ("The international law of the sea, namely the Convention, has only provided different rules for marine data collection at different locations, and it has not provided a categorization for each kind of marine data collection activity. This factor is exactly the main cause that leads to the international disagreement on jurisdiction over the military activities, such as collection of marine data for military purposes in EEZs.").

114. Sam Bateman, A Response to Pedrozo: The Wider Utility of Hydrographic Surveys, 10(1) CHIN. J. INT'L L. 177, 179 (2011) ("Pedrozo also claims that 'marine scientific research' and 'surveys' are different because they are sometimes referred to separately in UNCLOS. However, I believe this is an over-reading of the Convention. The use of separate terms provides a 'catch-all' phrase for the types of research activities that are either prohibited or require the authorization of the coastal State in particular circumstances. It is also significant that all the separate references to surveying activities are in the context of the passage regimes in UNCLOS rather than with regard to rights and duties in an EEZ. The main intent of the drafters of the Convention seems to have been more with prohibiting ships from conducting research or surveys during their passage through a territorial sea, a strait used for international navigation or archipelagic waters rather than with establishing a separate regime for hydrographic surveying.").

115. Jilu, supra note 61 , at 71 .

116. Haiwen, supra note 93, at 42.

117. Sam Bateman, Hydrographic Surveying in the EEZ: Differences and Overlaps with Marine Scientific Research, 29 MARINE POL'Y 163, 172 (2005). It should be noted, however, that Bateman does distinguish in particular intelligence collection as an activity that is separate, both in nature and in the technology it employs, from other marine surveying. Id. 
III." 118

When UNCLOS was drafted, hydrographic surveys effectively "had to be conducted with the consent of the coastal [S]tate as the surveys involved participation from land."119 Clearly, then, the original intention of the drafters was to consider these surveys, when conducted by third parties, as falling under the jurisdiction of the coastal State, since there was no other way of conducting them at the time. Why then should the introduction of the GPS in the 1990s (which alleviated any need for coastal State involvement and opened up the possibility for hydrographic surveying without that country's knowledge $)^{120}$ now be exploited by maritime powers to evade the jurisdiction of the coastal State?

One commentator also suggests that creating a separate category of "military activities," immune from scrutiny, will only induce States to rename certain vessels and activities disingenuously, in order to circumvent legal constraints imposed by coastal States. ${ }^{121}$ Another commentator notes that military hydrographic survey activities should in fact be viewed as a "type of battlefield preparation, and thus a threat of force against the coastal State ... violating the principle of peaceful use of the sea."122

For the reasons mentioned above, China enacted the "Surveying and Mapping Law of the People's Republic of China" by Presidential order in 2002. ${ }^{123}$ The law elaborated on the notion of surveying and mapping cited in the prior 1998 law, clarifying that "all surveying and mapping activities in the territorial air, land and waters of the People's Republic of China, as well as other sea areas under its jurisdiction," are bound by the provisions of Chinese law. ${ }^{124}$ Any such surveying and mapping activity must first obtain the approval of the competent authorities in the PRC. Operating without this permission would result in a fine of 500,000 yuan and expulsion

118. Sam Bateman, Hydrographic Surveying and Marine Scientific Research in Exclusive Economic Zones, in FrEEDOM OF SEAS, PASSAGE RIGHTS AND THE 1982 LAW OF THE SEA CONVENTION 105, 122 (Myron H. Nordquist et al. eds., 2009). Bateman also challenges the contention raised above by Pedrozo (supra note 69 and accompanying text) that hydrographic and MSR activities can be distinguished by their intended use. As countered by Bateman: "Indeed it makes no practical sense to suggest that the modern hydrographic surveying vessel will be restricting its operations purely to information required for the safety of navigation." Bateman, supra.

119. KLEIN, supra note 40, at 222.

120. Bateman, supra note 117 , at 168 .

121. Yu Zhirong, Jurisprudential Analysis of the U.S. Navy's Military Surveys in the Exclusive Economic Zones of Coastal Countries, in Military Activities IN THE EEZ: A U.S.-China Dialogue ON SECURITY AND INTERNATIONAL LAW IN THE MARITIME COMMONS 37, 44 (Peter Dutton ed., 2010). Zhirong specifically refers to a U.S. maritime research vessel, the R/G Roger Revelle, which, while being marked as belonging to "Scripps Institution of Oceanography, University of California," was owned by the U.S. Navy, and its use was approved by the Navy. Therefore, it met the requirements for an allegedly free from scrutiny "military survey," as opposed to an MSR, which requires prior consent. Id.

122. Gao, supra note 53, at 289.

123. Surveying and Mapping Law of the People's Republic of China (Order of the President No. 75) (Aug. 29, 2002), http://english1.english.gov.cn/laws/2005-10/09/content_75314.htm [https://perma.cc/FJ57-XMCC].

124. Id. art. 2. (emphasis added) 
from the country. ${ }^{125}$ Furthermore, the law makes clear that any such surveying or mapping "may not involve State secrets or endanger State security," further suggesting a strict prohibition on intelligence gathering for military purposes. ${ }^{126}$

\section{ii. "Due regard" obligations within the EEZ}

Prohibitionist scholars ascribe great weight to the "due regard" obligations of third States within the EEZ. According to their interpretation of the term, States are bound to refrain from any acts which might adversely affect the use of the EEZ by nationals of other States. ${ }^{127}$

This is of particular pertinence in the context of third States' over-flight freedoms above the zone. Articles 2 and 49 of UNCLOS ${ }^{128}$ and Article 1 of the 1944 Convention on International Civil Aviation ("Chicago Convention") ${ }^{129}$ reserve the airspace above the territorial sea and archipelagic waters to the sovereignty of the coastal/archipelagic State. However, this does not extend beyond the twelve nautical-mile limit. Therefore, unlike the waters of the zone, the coastal State lacks "a legal basis for regulating military activities in the airspace above the EEZ."130 The standard of "due regard" becomes the primary, if not sole, tool used by coastal States to limit third States' use of its EEZ airspace.

125. Pedrozo, supra note 48 , at 26 .

126. Surveying and Mapping Law of the People's Republic of China, supra note 123, art. 7.

127. See James Kraska, Resources Rights and Environmental Protection in the Exclusive Economic Zone, in Military Activities IN THE EEZ: A U.S.-China Dialogue ON SECURITY AND INTERNATIONAL LAW IN THE MARITIME COMMONS 75, 83 (Peter Dutton ed., 2010) (paraphrasing the standard set by the International Law Commission in its Commentary with regards to the High Sea).

128. UNCLOS, supra note 11, art. 2(1) ("The sovereignty of a coastal State extends, beyond its land territory and internal waters and, in the case of an archipelagic State, its archipelagic waters, to an adjacent belt of sea, described as the territorial sea"); art. 2(2) ("This sovereignty extends to the air space over the territorial sea as well as to its bed and subsoil"); art. 49(2) ("This sovereignty extends to the air space over the archipelagic waters, as well as to their bed and subsoil, and the resources contained therein").

129. Chicago Convention on International Civil Aviation, art. 1, Dec. 7, 1944, 61 Stat. 1180, 15 U.N.T.S. 295 ("The contracting States recognize that every State has complete and exclusive sovereignty over the airspace above its territory"); see also art. 3(d) ("The contracting States undertake, when issuing regulations for their state aircraft, that they will have due regard for the safety of navigation of civil aircraft").

130. Pedrozo, supra note 16, at 12. A similar conclusion was reached by the Secretariat of the International Civil Aviation Organization ("ICAO") in a 1987 study he conducted:

[F]or the purpose of the Chicago Convention, its Annexes and other international air law instruments, the exclusive economic zone is deemed to have the same legal status as the high seas and any reference in these instruments to the high seas should be deemed to encompass the exclusive economic zone.

Secretariat Study, Consideration of the Report of the Rapporteur on United Nations Convention on the Law of the Sea-Implications, if any, for the Application of the Chicago Convention, Its Annexes and Other International Air Law Instruments, Legal Committee, $26^{\text {th }}$ Sess., ICAO Doc. No. LC/26-WP/5-1 (Feb. 4, 1987). With regards to this study, Williams notes that: "The study's results have not been challenged, disputed, or superseded. ICAO did not further pursue the matter, and the study's results inform ICAO's governance to this day. ICAO's jurisdiction to legislate Rules of the Air over all areas previously considered high seas, to include the EEZ, continues unabated." Williams, supra note 52, at 53. 
While the permissivist approach seems to denote that the "due regard" standard should be equated with a technical and objective analysis of reasonableness, law of the sea jurisprudence takes a far less stringent route. In the Chagos Marine Protected Area Arbitration (Mauritius v. United Kingdom), the Annex VII Tribunal clarified the following:

[T] he ordinary meaning of "due regard" calls for [State A] to have such regard for the rights of [State $\mathrm{B}$ ] as is called for by the circumstances and by the nature of those rights. The Tribunal declines to find in this formulation any universal rule of conduct. The Convention does not impose a uniform obligation to avoid any impairment of [State B's] rights; nor does it uniformly permit the [State $\mathrm{A}]$ to proceed as it wishes, merely noting such rights. Rather, the extent of the regard required by the Convention will depend upon the nature of the rights held by [State B], their importance, the extent of the anticipated impairment, the nature and importance of the activities contemplated by [State A], and the availability of alternative approaches. ${ }^{131}$

Far from just a technical analysis of reasonableness, the Tribunal recognized the need to engage in a "balance of interests," a contextual analysis of the coastal State's rights (which could potentially take into account its subjective "eggshell skull"), and most importantly a requirement of proportionality. The use of the phrase "availability of alternative approaches," coupled with the requirement to examine "anticipated impairment" versus the "importance of the activities," echoes what Aharon Barak might call "necessity" and "proportionality" stricto sensu. For prohibitionists, such an open-ended test does leave room for "due regard" to potentially limit certain military and surveillance activities in the zone. ${ }^{132}$

\section{Prohibitive Narrative of the Treaty Negotiations}

Prohibitionists suggest that it is a misrepresentation of history to argue that the "majority of delegates" during UNCLOS III negotiations had indeed supported the U.S. position regarding coastal State security claims within the zone. ${ }^{133}$ In the name of multilateral compromise, UNCLOS III delegates declined to reach a resolution on this matter. ${ }^{134}$ To establish this theory, prohibitionists rely on the comments made by Tommy T.B. Koh, President of UNCLOS III, who had remarked on the issue in a Panel of the Center for Oceans Law and Policy in 2009:

The legal status of the Exclusive Economic Zone (EEZ) was another very

131. In re The Chagos Marine Protected Area Arbitration, I519 (March 18, 2015), http://www.pcacases.com/pcadocs/MU-UK\%2020150318\%20Award.pdf [https://perma.cc/EK8YAF39].

132. See generally Ahron Barak, Proportionality: Constitutional Rights and their LIMITATIONS 317-79 (2012). Note in particular the similarities and distinctions that Barak draws between proportionality and reasonableness. Id.

133. Haiwen, supra note 93, at 33.

134. See supra notes $13-14,86$ and accompanying text. 
contentious issue .... On this issue there were also strongly held and opposing views. Some coastal States would like the status of the EEZ to approximate legal status of the territorial sea. Many other states held the view that the rights of the coastal States and the EEZ are limited to the exploitation of living and non-living resources .... On this issue... there was no agreement. Castañada (Dr. Jorge Castañada, leader of the Mexican delegation to UNCLOS III - A.L.) and a Norwegian colleague, submitted a compromise text to the Conference. The text was strongly debated but found very wide acceptance. Not universal acceptance, but wide acceptance. There were friends on both sides who did not agree with the compromise text and held onto their strongly held initial positions. 135

\section{Prohibitive Understanding of State Practice}

Prohibitionists raise a post-colonial TWAIL-like critique of the notion that broad state practice actually exists to support third State military maneuvers within the zone. The following rhetorical question was raised by Dr. Haiwen, deputy director of the China Institute for Marine Affairs: "May I ask whether, throughout history, except for the United States and other developed countries, there are any developing coastal States who wantonly conducted marine data collection and military activities in the waters beyond and adjacent to the territorial sea of developed countries?"136 This seems to tie neatly to an earlier statement by Kuan-hua to the effect that there are no "open sea" freedoms, there is only a "private sea," controlled by those who have, to the disadvantage of those who do not.

It is on this basis that eighteen coastal States, Brazil, Uruguay, Kenya, Cape Verde, Iran, Pakistan, India, Bangladesh, Myanmar, Thailand, Cambodia, Malaysia, Vietnam, North Korea and China, all claim a security interest in the EEZ, "typically by restricting foreign flagged military activities" within and above the zone. ${ }^{137}$ To establish these claims, many

135. Tommy T.B. Koh, Remarks on the Legal Status of the Exclusive Economic Zone, in FrEEDOM of Seas, Passage Rights and the 1982 LaW of the Sea Convention 53, 53-54 (Myron H. Nordquist et al. eds., 2009) (emphasis added); see also id. at 47 ("Pedrozo states that '[t]he position ultimately accepted by the overwhelming majority of the delegations at UNCLOS III was that military operations, exercises and activities have always been regarded as internationally lawful uses of the sea and that the right to conduct such activities will continue to be enjoyed by all states in the EEZ.' However, he fails to provide evidence to prove his point of view. How 'overwhelming' was that 'majority'? Exactly which delegations did that 'majority' consist of? Contrary to his argument, no express agreement could be reached on this issue at that time, much less could this position be 'accepted by the overwhelming majority of the delegations'.").

136. Haiwen, supra note 93, at 37; see also Felipe H. Paolillo, The Exclusive Economic Zone in Latin American Practice and Legislation, 26 OCEAN DEV. \& INT'L L. 105, 107-08 (1995) ("It should not be surprising, then, that coastal states tend to respond to the questions that the Convention left unanswered or with respect to which participants at the Conference were forced to resort to "constructive ambiguity' by developing a practice that better meets their national interests.").

137. KRASKA \& PEDROZO, supra note 15, at 277-78; see also Guoxing, supra note 42, at 22 ("Since the formulation of the Convention, there have existed two opposite standpoints on the matter. The coastal states including Brazil, Cape Verde, Uruguay, India, Pakistan, Bangladesh, Malaysia and China oppose the military and information activities of other countries in their EEZs, which, they argue, jeopardize their security and violate the fundamental principle for peaceful uses of the seas"); Stephen 
of these States introduced security-related provisions into their domestic EEZ legislation. ${ }^{138}$ While at present this legislation "could well be construed as in violation of international law,"139 it does suggest a lack of unanimity with regards to the current formulation of the rules. In the words of Galdorisi and Kaufman, the significant coastal State domestic legislation notes that "the Convention is not the last and final word on the customary law of the sea in this area."140 Far from acquiescing to third States' intelligence gathering activities within their zones, coastal States have attempted, through "strong domestic laws," 141 to turn the EEZ into a "zone of absolute State control: in effect, an area of sovereignty." 142

Coastal States have responded in other ways as well, however. Consider, for example, the following incidents from the last two decades: the Peruvian Attack on a U.S. C-130 State Aircraft (1992); ${ }^{143}$ Peruvian refusal to permit entry into the Peruvian Oceanic Flight Information Region for two U.S. C-130 State Aircraft (1995); ${ }^{144}$ Chinese Jianheu III-Class frigate interception of the USNS Bowditch (T-AGS 62) hydrographic survey ship in the Yellow Sea (2001); ${ }^{145}$ the collision between a U.S. Navy EP-3E ARIES Signals Intelligence aircraft and a PRC interceptor fighter jet off Hainan Islands (2001); ${ }^{146}$ the Impeccable Incident (2009); ${ }^{147}$ Chinese Navy harassment of the Indian Naval ship Airavat in the South China Sea

Rose, Naval Activity in the EEZ - Troubled Water Ahead?, 39 NAVAL L. REV. 67, 134 (1990).

138. For a review of this legislation, see, e.g., KRASKA \& PEDROZO, supra note 15, at 277-78; Galdorisi \& Kaufman, supra note 10, at 282-83 ("Uruguay, for example, takes the position that the Convention does not explicitly permit the same range of uses associated with warship operation in the EEZ as are permitted on the high seas. Brazil has enacted domestic legislation that states: 'In the exclusive economic zone, military maneouvres [sic], in particular those involving the use of weapons or explosives, may only be carried out by other States with the consent of the Brazilian Government.' By legislation enacted on May 2, 1993, Iran flatly prohibited 'foreign military activities and practices' within its EEZ. Similarly, India, Malaysia, and Pakistan have all made claims that would restrict naval activities in their EEZs without prior permission.").

139. KLEIN, supra note 40, at 47.

140. Galdorisi \& Kaufman, supra note 10 , at 283 .

141. Id. at 288 .

142. Robert Nedelson, The Exclusive Economic Zone State Claims - and the LOS Convention, 16 MARINE POL'Y 463, 483 (1992).

143. KRASKA \& PEDROZO, supra note 15, at 230 ("On April 25, 1992, Peruvian fighter jets shot at a U.S. Propeller-driven C-130 aircraft that was conducting a routine counterdrug surveillance mission off the Peruvian Coast, but outside of Peru's territorial sea and national airspace. One crewmember was killed; two were injured. The U.S. airplane was forced to make an emergency landing at a small airstrip in Talara, Peru, near the border with Ecuador. Although Peru expressed regret for the incident, Peruvian Authorities justified their action by alleging that the U.S. aircraft was hundreds of miles off course and that it had failed to respond to several attempts to establish visual and radio warnings by the two fighter jets.")

144. Id.. at 230-31 ("[I]n 1995 two C-130s were require to abort their mission after Peruvian refusal to permit entry into the Flight Information Region (FIR) without diplomatic clearance. The flight controllers demanded that the aircraft remain west of 90 degrees west longitude- 650 nautical-miles from the Peruvian coastline.").

145. Raul Pedrozo, Close Encounters at Sea: The USNS Impeccable Incident, 60 NAVAL WAR C. REV. 101, 101 (2009).

146. Hayashi, supra note 8, at 130-35.

147. See supra notes $81-82$ and accompanying text. 
(2011); ${ }^{148}$ Chinese Navy Ship harassment of a U.S. Navy guided missile cruiser Cowpens in the South China Sea (CG-63) (2013); ${ }^{149}$ European Responses to Russian aerial and naval "brinkmanship" policy following the Ukrainian Crisis (2014); ${ }^{150}$ the Chinese fighter interception of a U.S. Navy P-8 maritime patrol aircraft east of Hainan Islands (2014); ${ }^{151}$ a Chinese fighter's engagement in what Americans referred to as "unsafe maneuvers" near a U.S. RC-135 surveillance aircraft above the Yellow Sea (2015); ${ }^{152}$ the interception of a U.S. Navy EP-3 by two Chinese Shenyang J-11 fighters over the South China Sea, with one fighter coming within fifty feet of the aircraft (2016); ${ }^{153}$ the interception of a U.S. RC-135 by a Chengdu J-10 fighter within 100 feet over the East China Sea (2016); ${ }^{154}$ and the interception of a U.S. EP-3 surveillance aircraft over the East China Sea by Chinese fighter jets (2017). ${ }^{155}$ To this list we should add that a number of coastal States "have issued diplomatic protests when U.S. Naval vessels have operated in their EEZ," the biggest protester being India. ${ }^{156}$ This enumeration, and in particular the recent rise in the quantity and intensity of incidents, would seem to suggest that the EEZ surveillance question is far from resolved.

Finally, with regard to the argument of a "double standard" by the $\mathrm{PRC}$, at least two different explanations can be put forward with regard to the logic behind PRC's surveillance in American, and more recently Australian, EEZs. One commentator captured the first explanation by suggesting, "I demand freedom from you in the name of your principles. I deny it to you in the name of mine."157 Under this logic the Chinese interpretation of UNCLOS' EEZ provisions is one which grants the coastal

\footnotetext{
148. O'ROURKE, supra note 18 , at 11 .

149. Id. at 10 .

150. Lizzie Dearden, Full List of Incidents Involving Russian Military and Nato Since March 2014,
} THE INDEPENDENT (Nov. 10, 2014), www.independent.co.uk/news/world/europe/full-list-of-incidentsinvolving-russian-military-and-nato-since-march-2014-9851309.html [https://perma.cc/6DJD-XGUL]; see also, Frear, Kulesa \& Kearns, Dangerous Brinkmanship: Close Military Encounters Between Russia and the West in 2014, EUROPEAN LEADERSHIP NETWORK (Nov., 2014) www.europeanleadershipnetwork.org/medialibrary/2014/11/09/6375e3da/Dangerous\%20Brinkmanshi p.pdf [https://perma.cc/238Y-EAV9].

151. O'ROURKE, supra note 18 , at 10 .

152. Id.

153. Id.

154. Id

155. Id.

156. Guoxing, supra note 42, at 21; Maritime Sovereignty in the East and South China Seas: Hearing Before the H. Joint Subcomm. of Foreign Affairs Subcomm. on Asia and the Pacific \& Armed Services Subcomm. on Seapower \& Projection Forces, 113th Cong., at 4 (2014) (statement of Jeff M. Smith, Director of South Asia Programs, American Policy Council), http://docs.house.gov/meetings/FA/FA05/20140114/101643/HHRG-113-FA05-Wstate-SmithJ20140114.pdf [https://perma.cc/5YQA-S8QJ] ("The important distinction is that while some countries have issued diplomatic protests when U.S. naval vessels have operated in their EEZ without consent, only China has 'operationally challenged' U.S. warships on multiple occasions, resulting in several dangerous confrontations at sea, the most recent involving the USS Cowpens in December, 2013.") [hereinafter Testimony of the Director of South Asia Programs].

157. See, e.g., Erickson \& Bruyere, supra note 18. 
State the power to enforce its security interests in the zone. But that is the prerogative of the coastal State. To the extent that that State decides not to adopt such policies, third States retain their complete freedom of navigation rights. In other words, China is entitled to spy in America's EEZ because the latter did not adopt legislation to the contrary, but the United States is forbidden from doing the same in China's EEZ because China has legislated in that fashion. ${ }^{158}$ An alternative explanation could be simple countermeasures. Under international law, an injured State may take actions against the State who has committed an internationally wrongful act in order to induce that State to comply with its obligations. ${ }^{159}$ From the perspective of China, spying in the EEZ of the United States would thus be a wrongful act, the wrongfulness of which is nullified, as its purpose is to induce the United States to end its wrongful activity, its very surveillance in China's EEZ.

A significant number of legal scholars have tended to "support the legality of intelligence gathering by third states in the EEZ."160 Nonetheless, when permissivist and prohibitionist arguments are considered side-by-side, they seem to balance each other off. This makes sense, given the fact that the subject matter for treaty interpretation in our analysis (i.e. intelligence gathering under UNCLOS) is an "unspecified grey area" left intentionally unresolved by the drafters. ${ }^{161}$ Relying on traditional treaty interoperation approaches seems only to further anchor permissivist and prohibitionist scholars to their "high horse of principle."162 In this context, the November 2014 US-China Memorandum of Understanding (MOU) on Air and Maritime Encounters, which was praised by some as a positive step towards stability and cooperation in the region, did not resolve the core of the issue at hand. As noted by Dr. Valencia:

The MOU has several weaknesses. For starters the annex on air-to-air encounters has yet to be completed, indicating continuing disagreement in this sphere. Moreover, the agreement is "not intended to be binding under international law" and can be discontinued by either side. But the most glaring loophole is that the agreement is made "without prejudice"

158. Id.

159. Draft Articles on Responsibility of States for Internationally Wrongful Acts, Int'l Law Comm'n, Rep. on the Work of Its Fifty-Third Session, U.N. Doc. A/56/10, art. 49(1) (Nov. 2001).

160. See, e.g., KLEIN, supra note 40, at 221; KRASKA \& PEDROZO, supra note 15, at 311-12; Kaye, supra note 7, at 104; Hayashi, supra note 8, at 130; Elmar Rauch, Military Uses of the Oceans, 28 GERMAN Y.B. INT'L L. 229, 252 (1985); Walter F. Doran, An Operational Commander's Perspective on the 1982 LOS Convention, 10 INT'L J. MARINE \& COASTAL L. 335, 335 (1995); Barbara Kwiatkowska, Military Uses in the EEZ - a Reply, 11 MARINE POL'Y 249, 250 (1987); Jean-Pierre Quéneudec, Zone Economique Exclusive et Forces Aéronavales, in THE MANAGEMENT OF HUMANITY'S RESOURCES: THE LAW OF THE SEA 319, 322-24 (Rene-Jean Dupuy ed., 1982).

161. Guoxing, supra note 42, at 22; see supra notes $13-14$ and accompanying text.

162. Wachman, supra note 20 , at 111 . 
to either side's starkly different policy perspectives on military activities in China's EEZ.... According to General Fan Changlong, Vice Chairman of China's Central Military Commission "the United States should halt its 'close-in' aerial and naval surveillance of China." ... . In practical terms, Admiral Jonathan Greenert, U.S. Chief of Naval Operations said, "we'll continue to operate in international airspace; we made that clear and we'll proceed ahead." These differences are crystal clear and remain unaddressed. ${ }^{163}$

In any event, future reliance on that agreement to further consolidate around rules of the road seems looming, as the Trump Administration recently launched its first Freedom of Navigation Operation (FONOP) in the South China Sea since taking office. The operation signaled more of the same from the American administration and provoked a predictable condemnation and protest from the PRC. ${ }^{164}$ Moreover, a recent tweet from President Trump on the North Korea issue seemed to suggest greater antagonism and a lack of potential cooperation with Pyongyang. ${ }^{165}$

One of the greatest contributions of Peruvian Ambassador Jorge Castañeda, during UNCLOS III treaty negotiations was the introduction of the wording to UNCLOS Article 59. The Article aimed to address the delicate problem of "residual rights" within the zone, stressing that:

In cases where [UNCLOS] does not attribute rights or jurisdiction to the coastal State or to other States within the exclusive economic zone, and a conflict arises between the interests of the coastal State and any other State or States, the conflict should be resolved on the basis of equity and

163. Mark J. Valencia, The US-China MOU on Air and Maritime Encounters, THE DIPLOMAT (Nov. 17, 2014), http://thediplomat.com/2014/11/the-us-china-mou-on-air-and-maritime-encounters/ [https://perma.cc/83CA-K5MY] (emphasis added); see also GOLDSTEIN, supra note 80, at 287-88 ("[W]e may wish to think that tensions will dissipate if we develop such 'codes of conduct' or 'rules of the road,' but one cannot remove the strategic, political, and indeed symbolic ramifications of close-in surveillance without addressing them head on.").

164. Julian Ku, The US Conducts the First South China Sea Freedom of Navigation Operation of the Trump Era, but It Was "Off the Record", Lawfare (25 May 2017), https://www.lawfareblog.com/usconducts-first-south-china-sea-freedom-navigation-operation-trump-era-it-was-record

[https://perma.cc/VS38-H43S ] (The off-the-record approach "makes sense if the intended audience of a FONOP is only the other country whose legal claim you are challenging (in this case, China). Indeed, the FONOP program was created in 1979 with little fanfare and many FONOPs are conducted every year all over the world without any public notice except by the countries involved. But FONOPs in the South China Sea are no longer just elegant forms of state-to-state legal dialogues. They have, for better or for worse, become the main vehicle for the U.S. government to signal its commitment to maintaining a presence in the South China Sea amidst China's expansive land-reclamations and growing naval presence .... Of course, there is one more unintended consequence of leaking the details of FONOPs: China now must publicly react lest it be seen as not sufficiently attentive to its own sovereignty. So, as if on cue, China's Ministry of National Defense denounced the USS Dewey operation as 'muscleflexing' while China's Ministry of Foreign Affairs expressed 'strong dissatisfaction' while announcing the Dewey was 'expelled.' But this sharp public reaction of the Chinese government will now lead to even more pressure on the Trump Administration to demonstrate even more firmness with even more FONOPs, lest the U.S. be seen as backing down to the Chinese. (Rinse, wash, and repeat.).").

165. Jacob Pramuk, Trump Suggests the Pressure on China over North Korea May Just be Beginning, CNBC (July 5, 2017 12:20 PM), https://www.cnbc.com/2017/07/05/trump-north-koreatweets-suggest-more-action-against-china-may-come.html [https://perma.cc/79Z8-7BFH] (citing Donald J. Trump (@realDonaldTrump), TwITTER,

https://twitter.com/realDonaldTrump/status/882560030884716544 [https://perma.cc/SUL5-GNKU] ("So much for China working with us - but we had to give it a try!")). 
in the light of all the relevant circumstances, taking into account the respective importance of the interests involved to the parties as well as to the international community as a whole. ${ }^{166}$

As explained by Ambassador Castañeda:

The central problem was still the "residual rights" not attributed specifically by the Convention either to coastal States o[r] to third States. These rights could refer to future activities, such as uses of the sea not yet discovered or certain military uses not contemplated in the draft Convention, but traditionally practiced without any restriction by military powers in the high seas. ${ }^{167}$

This guideline for resolution of disputes within the zone seems relevant in addressing the EEZ surveillance issue. ${ }^{168}$ If we accept that intelligence gathering within the zone was intentionally left outside the ambit of UNCLOS, and if we consider the vast technological advancements that have taken place since the adoption of UNCLOS, there could be a basis to argue that third States' surveillance within the EEZ should be understood as a "residual right". ${ }^{169}$ Therefore a contextual analysis of particular intelligence operations is crucial in determining their legitimacy. It is not a binary world, as permissivists and prohibitionists would have us believe. We need to consider the functional purpose of intelligence in international law, and international maritime law in particular, and examine the factual matrix surrounding each intelligence operation in light of general principles of equity and the interests of the international community writ large. ${ }^{170}$ This kind of multifaceted review of the EEZ surveillance conundrum is attempted in Sections III and IV of this paper.

\section{BETWEEN DRAGON-KINGS, SOARING SNAKES, AND EARTHWORMS}

As we have thus far seen, the discourse over intelligence gathering in

166. UNCLOS, supra note 11, art. 59.

167. Jorge Castañeda, Negotiations on the Exclusive Economic Zone at the Third United Nations Conference on the Law of the Sea, in ESSAYS IN INTERNATIONAL LAW IN HONOUR OF JUDGE MANFRED LACHS 605, 620 (Makarczyk ed., 1984).

168. Id. at 614 ("Precisely, because the zone was defined as a sui generis zone, which was neither territorial sea nor high seas, it was indispensable to rely on some guideline or criterion to settle disputes that might arise out of concurrent uses of the sea within the exclusive economic zone, that is by the presence of competitive rights between the coastal State and the other States.”); 3 EDWARD D. BROWN, The UN CONVENTION ON THE LAW OF THE SEA, 1982: A Guide fOR NATIONAL Policy MaKing LEGISLATION AND ADMINISTRATION 171 (1991) ("Opinions differ as to whether such military uses of the EEZ is a freedom or lawful use attributed to other States in Article 58 of the UN Convention or an unattributable or residual use under Article 59."); Pedrozo, supra note 48, at 24 ("China's current efforts to use article 59 to argue that it retains certain residual rights in the EEZ is simply an attempt to resurrect the argument it made and lost at UNCLOS III regarding security interests in the EEZ. China's effort to include security interests in the bundle of rights retained by the coastal state in the EEZ was rejected at UNCLOS III. Therefore, there is no conflict with regard to coastal-state security interests to resolve under article 59 - such interests simply do not exist in the EEZ.").

169. Consider, however, that UNCLOS Article 298(1)(b) specifically excludes military activities by government vessels and aircraft as well as disputes concerning enforcement activities in the exercise of sovereign rights from the jurisdiction of UNCLOS dispute resolution mechanism. UNCLOS, supra note 11, art. 298(1)(b). Therefore, there is room to challenge the applicability of Article 59 in this light.

170. VICUÑA, supra note 13 , at 35 . 
the EEZ has been, to a large extent, subsumed by the broader discourse over military activities within and above the zone. Insufficient attention has therefore been given to the lex specialis of the International Law of Intelligence ("ILI") in addressing this pertinent question. This is disconcerting, as the Dragon-Kings are not any different than their brothers and sisters, the Soaring Snakes ("Tengshe") or the Earthworms ("Dilong"). ${ }^{171}$ Indeed, naval reconnaissance is only one aspect within a broader canopy of intelligence gathering options available to States, from aerial surveillance to the sending of spies, and from governmental hacking to the gathering of information in the course of regular diplomatic engagements. Any conclusion as to which reconnaissance activity constitutes or should constitute an "international lawful use" (i.e. which activities serve or should be deemed to serve "peaceful purposes") must draw its guidance from a broader analysis of the permissibility and legality of intelligence collection, as a whole, under international law.

The difficulty, however, in approaching this kind of an analysis is that traditional wisdom assumes that intelligence gathering seems to exist in a "legal penumbra, lying at the margins of diverse legal regimes and at the edge of international legitimacy." 172 This ominous contention is one shared by many, if not most, international legal scholars. ${ }^{173}$ For them, any attempt

171. See generally Michael Carr, Chinese Dragon Names, in 13(2) Linguistics of THE TiBETOBURMAN AREA 87 (1990).

172. Simon Chesterman, The Spy Who Came in from the Cold War: Intelligence and International Law, 27 Mich. J. INT'L L. 1071, 1072, 1129-30 (2006) (citations omitted) ("Despite its relative importance in the conduct of international affairs, there are few treaties that deal with it directly. Academic literature typically omits the subject entirely, or includes a paragraph or two defining espionage and describing the unhappy fate of captured spies. For the most part, only special regimes such as the laws of war address intelligence explicitly. Beyond this, it looms large but almost silently in the legal regimes dealing with diplomatic protection and arms control."); see also Daniel B. Silver, Intelligence and Counterintelligence, in NATIONAL SECURITY LAW 935, 965 (John Norton Moore \& Robert F. Turner eds., 2d ed. 2005). Silver shares a similar view to Chesterman's: "There is something almost oxymoronic about addressing the legality of espionage under international law . . . . [D] espite the ambiguous state of espionage under international law, it is not specifically prohibited by treaty or other international legal mechanism." Id.

173. See, e.g., RichaRd FALK, ESSAYS ON ESPIONAGE AND INTERNATIONAL LAW (Stranger ed., 1962) ("[T]raditional international law is remarkably oblivious to the peacetime practice of espionage. Leading treatises overlook espionage altogether or contain a perfunctory paragraph that defines a spy and describes his hapless fate upon capture."); W. Hays Parks, The International Law of Intelligence Collection, in NATIONAL SECURITY LAW 433, 433-34 (Moore, Tipson, Turner eds., 1st ed. 1990) ("No serious proposal ever has been made within the international community to prohibit intelligence collection as a violation of international law because of the tacit acknowledgement by nations that it is important to all, and practiced by each."); Geoffrey Dermarest, Espionage in International Law, 24 DENV. J. INT'L. L. \& POL'Y 321, 321 (1996) (“International law regarding peacetime espionage is virtually unstated, and thus international law has been an inappropriate and inadequate reference for either condemnation or justification of actions involving intelligence gathering."); Christopher D. Baker, Tolerance of International Espionage: A Functional Approach, 19 AM. U. INT'L. L. REV. 1091, 1091 (2004) ("Espionage is curiously ill-defined under international law, even though all developed nations, as well as many lesser-developed ones, conduct spying and eavesdropping operations against their neighbors."); Symposium on State Intelligence Gathering and International Law, 2007 Brochure, Michigan Journal of International Law, in John Radsan, The Unresolved Equation of Espionage and International Law, 28 MiCH. J. INT'L L. 595, 596 (2007) (“While states may regulate intelligence gathering domestically, no significant treaties or conventions address the process, nor is it subject to any internationally recognized set of principles or standards .... [T]he lacuna in international law on these 
to extrapolate the lex lata corpus of the ILI, let alone its lex scripta, would inevitably prove to be a failed attempt, as there is simply nothing to extrapolate. ${ }^{174}$ In fact, the notion that international law is moot as to the question of if, when, and how intelligence is to be collected or dispersed has been repeated so many times that it has reached mythical proportions. ${ }^{175}$ Recently, a group of nineteen renowned international law experts concluded that "customary international law does not prohibit espionage per se.... $[\mathrm{T}]$ he Experts concurred that insufficient State practice and opinion juris on the matter exist to so conclude." 176 This fiction forms the basis for a Lotus world of action, ${ }^{177}$ one in which "[S]tates may spy on each other- and on each other's nationals- without restriction," 178 justifying their behavior

matters ... suggests a clear need for focused discussion.”); Jeffrey H. Smith, Keynote Address: State Intelligence Gathering and International Law, 28 MiCH. J. INT’L L. 543, 544 (2007) (“[M]ost lawyers would likely scoff at the notion that espionage activities are constrained in any meaningful way by international law. Indeed most probably believe that international law's only influence on espionage is that in wartime, spies caught behind the lines out of uniform can be shot. Hardly a sophisticated or, to intelligence services, comforting notion."); Martin Scheinin, Report of the Special Rapporteur on the Promotion and Protection of Human Rights and Fundamental Freedoms while Countering Terrorism, A/HRC/10/3, 9 (Feb. 4, 2009) (" $[\mathrm{N}]$ o general norm exists in international law expressly prohibiting or limiting acts of intelligence gathering."); Gary D. Brown \& Andrew O. Metcalf, Easier Said Than Done: Legal Reviews of Cyber Weapons, 7 J. NAT'L SEC'Y L. \& POL'Y 115, 116 (2014) (“[T]here is a longstanding (and cynically named) 'gentleman's agreement' between nations to ignore espionage in international law.").

174. Peyton Cooke, Bringing the Spies in from the Cold: Legal Cosmopolitanism and Intelligence Under the Laws of War, 44 U.S.F. L. REV. 601, 609-10 (2010) (citations omitted) ("Very little international law addresses intelligence. Indeed, beyond bilateral and multilateral intelligence-sharing treaties, which do not address intelligence methods, no in-depth treatment of intelligence exists in international law. While some bodies of international law, such as the law of war or human rights law, can potentially provide for very substantial intelligence oversight, the international law of intelligence itself does not. Intelligence-as-intelligence occupies a very murky place in international law that might be characterized as either legal but discouraged, or illegal but not enforced. To the extent that international intelligence law exists, it does not provide an effective mechanism for intelligence regulation.").

175. Glenn Sulmasy \& John Yoo, Counterintuitive: Intelligence Operations and International Law, 28 MiCH. J. INT'L L. 625, 637-38 (2006) (“International law has never prohibited intelligence collection, in peacetime or wartime.... The history of state practice reveals that the regulation of intelligence gathering has always been left to domestic enforcement.... Calls to pursue the establishment of international entities or international law to regulate the intelligence-collection activities of nationsstates are counterproductive.").

176. TALLinN MANUAL 2.0 ON THE INTERNATIONAL LAW APPLiCABLE TO CyBER OPERATIONS 169 (Michael N. Schmitt ed., 2d ed. 2017) (citations omitted).

177. See S.S. Lotus (Fr. V. Turk.), 1927 P.C.I.J. (ser. A) No. 10 (Sept. 7); cf. Accordance with International Law of the Unilateral Declaration of Independence in Respect of Kosovo, Advisory Opinion, 2010 I.C.J Rep. 478, 480-481, ๆๆ 8-9 (July 22) (declaration by Simma, J.) (“[U]nder this approach, everything that is not expressly prohibited carries with it the same colour of legality: it ignores the possible degrees of non-prohibition, ranging from 'tolerated' to "permissible" to 'desirable' ... the Court could have explored whether international law can be deliberately neutral or silent on a certain issue and whether it allows for the concept of toleration, something which breaks from the binary understanding of permission/prohibition and which allows for a range of non-prohibited options. That an act might be 'tolerated' would not necessarily mean that it is 'legal,' but rather that it is 'not illegal.' In this sense, I am concerned that the narrowness of the Court's approach might constitute a weakness, going forward, in its ability to deal with the great shades of nuance that permeate international law.").

178. Ashley Deeks, An International Legal Framework for Surveillance, 55 VA. J. INT'L L. 291, 301 (2015) ("Several government officials and scholars believe that the Lotus approach provides the best way to think about spying in international law. For them, the idea is simply that nothing in international law forbids states from spying on each other; states therefore may spy on each other - and each other's nationals - without restriction. Spying is therefore unregulated in international law."). 
through the argumentum ad hominem of "tu quoque."179

Such a depiction of the law and practice of intelligence collection is, however, misleading. A closer look at the literature would guide us to a different strand of legal thought, one which ventures into a more nuanced analysis of the existence and scope of the ILI. Professor Forcese has, for example, noted that any ambivalence as to the level of ILI's development should not be read as meaning that "spying exists in an international legal limbo," since "many rules of international law may be engaged by spying, depending on the nature of that spying and its geographic location."180 A similar rebuttal of the "regulatory black-hole" premise was put forward by Professor Chesterman:

What, then- if anything- does international law have to say about [intelligence gathering]? A surprising amount, though the surprise comes largely from the fact that the issue tends to be approached indirectly: intelligence is less a lacuna in the legal order than it is the elephant in the room $^{181}$

The intelligence Elephant was certainly there during UNCLOS III negotiations, though, as suggested above, delegates simply refused to acknowledge it. In attempting to diffuse the legal debate surrounding the prudency and lawfulness of reconnaissance activities within and above the EEZ, one must, from the outset, try to define the contours of this mysterious four-legged creature. Within the limits of this Article, I wish to make only two observations about the beast: one looks at its inherently dual nature and the other relates to its constantly evolving shape, as affected by the fast pace of modern technological advancement.

\section{A. The Right to Spy, Abuse of Rights, and the Dual Nature of Intelligence}

The territory of a State, its national airspace, its internal waters and territorial seas, are all subject to that State's control and must be respected as such by all other States. ${ }^{182}$ This customary principle is closely linked in

179. U.S DEP'T OF DEF., OfF. OF GEN. COUNS., AN ASSESSMENT OF INTERNATIONAL LEGAL IsSUES IN INFORMATION OPERATIONS 46 (1999), www.au.af.mil/au/awc/awcgate/dod-io-legal/dod-io-legal.pdf [https://perma.cc/7JND-LJY7] ("The lack of strong international legal sanctions for peacetime espionage may also constitute an implicit application of the international law doctrine of 'tu quoque' (roughly, a nation has no standing to complain about a practice in which it itself engages)."). Some American commentators have in fact argued tu quoque against China, stressing that, despite its rhetoric, it itself had increased the number of its military incursions, including survey and surveillance activities, within the EEZs of its neighbors, namely Japan, the Philippines, South Korea and Vietnam. See Pedrozo, supra note 16, at 16-18 ("China's position with regard to foreign military activities in the EEZ is selfserving at best and disingenuous at worst. As China continues to develop a blue water naval capability and expand its submarine fleet, Chinese ships and aircraft are increasingly operating in foreign EEZs throughout the Asia-Pacific region.").

180. Craig Forcese, Spies Without Borders: International Law and Intelligence Collection, 5 J. NAT'L SEC. L. \& POL'Y 179, 185 (2011); see also, Parks, supra note 173, at 433 ('Intelligence collection as such does not violate international law. However, some aspects of international law affect the means to be utilized in collection.").

181. Chesterman, supra note 172, at 1072 .

182. JOHN KISH, INTERNATIONAL LAW AND ESPIONAGE 83 (1995) ("The general principle of 
international law with the prohibition on the use of force and the doctrine of non-intervention, both enshrined in the United Nations Charter. ${ }^{183}$ Following a doctrinal interpretation of the law, one may conclude that: "intelligence gathering within the territorial confines of other states constitutes an unlawful intervention," 184 or to the very least an interference of a State's sovereignty. ${ }^{185}$ On the other hand, intelligence gathering outside those territorial bounds, such as espionage conducted from the global commons (in the high seas, in international airspace, and in outer space) seems to be, on its face, not subjected to these restrictions. ${ }^{186}$ Even if one accepted the doctrinal approach, the unique sui generis status of the EEZ (as the meeting point between coastal States' rights and high-seas freedoms) does not allow us to reach any meaningful conclusions and thus brings us back to square one.

But perhaps this doctrinal dichotomy is shortsighted, and traditional wisdom on the law of espionage is flawed. Under this logic one can contend that we have focused too much of our attention on delimiting the legality of espionage on the basis of fictional jurisdictional lines, ${ }^{187}$ whereas in reality,

exclusive sovereignty over national territory is firmly established in customary international law .... In particular, no State is entitled to carry out strategic observation in the national territory of another State without specific agreement.").

183. Military and Paramilitary Activities in and Against Nicaragua (Nicar. V. U.S.), Judgment 1986 I.C.J. 14, 212 (June 27); U.N. Charter art. 2(1) (1945) ("The Organization is based on the principle of the sovereign equality of all its Members."); art. 2(4) ("All Members shall refrain in their international relations from the threat or use of force against the territorial integrity or political independence of any state, or in any other manner inconsistent with the Purposes of the United Nations."); art. 2(7) ("Nothing contained in the present Charter shall authorize the United Nations to intervene in matters which are essentially within the domestic jurisdiction of any state...."); see also United Nations General Assembly Resolution 2625 (XXV) Declaration on Principles of International Law Concerning Friendly Relations and Co-operation Among States in Accordance with the Charter of the United Nations, on the Principle Concerning the Duty Not to Intervene in Matters Within the Domestic Jurisdiction of any State, in Accordance with the Charter, A/RES/25/2625 (1970) ("No State or group of States has the right to intervene, directly or indirectly, for any reason whatever, in the internal or external affairs of any other State. Consequently, armed intervention and all other forms of interference or attempted threats against the personality of the State or against its political, economic and cultural elements, are in violation of international law.").

184. Myres S. McDougal, Harold D. Lasswell, \& W. Michael Reisman, The Intelligence Function and World Public Order, 46 TEMP. L.Q. 365, 394 (1973).

185. We might find a basis for this argument from within UNCLOS. Indeed the drafters assumed, in the context of innocent passage within territorial waters that "any act aimed at collecting information to the prejudice of the defence or security of the coastal State" is a priori prejudicial to peace, good order, and security. UNCLOS, supra note 11, art. 19(2)(c). This is pertinent, as Article 19(2)(c) is the only article in the Convention to directly address intelligence gathering. In fact, the original wording of earlier drafts of this Article were even more explicit. Instead of the washed-up terminology of "collecting information," they included reference to "any act of espionage" and to "any act aimed at interfering with any systems of communication of the coastal state." Id. art. 19(2)(k). What is clear is that the drafters treated with suspicion surveillance activities in the territorial sea, further solidifying the notion that there is something more problematic with intelligence gathering by one State from within the territory or jurisdiction of another. $C f$. discussion infra Section III.B.

186. James Kraska, Putting Your Head in the Tiger's Mouth: Submarine Espionage in Territorial Waters, 54 COLUM. J. TRANSNAT'L L. 164, 173 (2015).

187. See, e.g., FABIEn Lafouasse, L'espionage dans le Droit InTERnational 27-28 (2012). Lafouasse distinguishes between two categories of acts of espionage: those which "collaterally lead to an attack on the territorial integrity (land, sea, or air)" of the spied state, and those which do not involve "an intrusion into foreign territory, since they are essentially carried out using technical means from the 
both tolerated and non-tolerated acts of espionage occur in all spaces (territorial and international). We should thus attempt to go deeper into reconceptualizing the right to spy under international law.

As I have written elsewhere, one can identify scores of sources in international law to establish the existence of the Jus Ad Explorationem (the "Right to Spy"). So much so, in fact, that "to claim that espionage is not $a$ priori permissible as a sovereign prerogative is simply inconceivable in our public world order" and certainly in discontent with both vast bodies of law and practice. ${ }^{188}$ However, the existence of a right to spy does not give a State a blank check to engage in espionage whenever it so chooses or to select means for surveillance without limitations. Quite the opposite, the right to spy, as I suggest, is merely a "derivative" right, a liberty right in Hohfeldian terms, not a right proper. ${ }^{189}$ As such, it is grounded in a limited set of justification and use restrictions. Uncle Ben said it best when he told Spider-Man that "with great power comes great responsibility," and so the power of a State to spy might be corrupted or abused if not used for the right purpose or if not meeting the golden standard (causing more harm than good).

The Doctrine of "Abuse of Rights" has its origins in canonical Roman law which recognized the legal maxim "neminem laedit qui suo jure utitur, meaning that nobody harms another when he exercises his rights." 190 The doctrine has since been recognized as a general principle of international law, ${ }^{191}$ and is commonly cited in the writings of publicists and in early cases of the PCIJ. 192 Professor Kiss suggested that in inter-State relations "the

very territory of the spying State or from international spaces, that is to say from spaces escaping the appropriation and territorial sovereignty of States (such as the high seas, and outer space)." In figure 3 in the book, Lafouasse goes even further to suggest that the first category of espionage results in triggering the international responsibility of the spying state, whereas the latter would not.

188. Asaf Lubin, A Principled Defence of the International Human Right to Privacy: A Response to Frédéric Sourgens, 42 YALE J. INT'L. L. ONLINE 1, 10-11 ("In actuality, one can identify a plethora of legal sources that recognize, what I have termed the jus ad explorationem, a derivative right of the State to peace-time intelligence gathering. These sources include the right of states to survival, recognized by the ICJ in the Nuclear Weapons advisory opinion (and the related collective right of selfdetermination of peoples); the laws on the use of force (and their recognition of a customary right for anticipatory self-defense); international human rights law (and the obligation of states to respect and ensure the right to life, liberty, and security of all persons subject to their jurisdiction); international humanitarian law (and the obligation of States to develop effective intelligence systems in preparation for war); collective security under U.N. Law (and the obligations of States under both treaty law and United Nations Security Council Resolutions to participate in the maintenance of international peace and security including through the sharing of intelligence to counter terrorism and the proliferation of WMDs, and to ensure the success of sanctions regimes); international disaster response laws and international environmental laws (which mandate cooperation in intelligence-gathering); and international accountability regimes (which depend on effective factual determinations that, in some cases, can only be achieved through continuous monitoring)").

189. For further analysis, see Asaf Lubin, Espionage as a Sovereign Right Under International Law and Its Limits, 24 INT'L L. STUDENTS ASS'N Q. 22, 24 (Feb. 2016).

190. Alexandre Kiss, Abuse of Rights, in 1 MAX Planck ENCYClOPEdia of Public INTERNATIONAL LAW 4 (2006).

191. See, e.g., BROWNLIE'S PRINCIPLES OF INTERNATIONAL LAW 562 (Crawford ed., 8th ed. 2012); OPPENHEIM's INTERNATIONAL LAW 407-09 (Robert Jennings \& Arthur Watts eds., 9th ed. 1992).

192. Fourth Report on State Responsibility by Mr. F.V. Garcia-Amador, Special Rapporteur, 2 Y.B. 
concept of abuse of rights may arise in three distinct legal situations."193 For the purposes of this Article, I only wish to focus on two of these three situations.

The first concerns situations where Country A exercises its right intentionally "for an end which is different from that for which the right has been created, with the result that injury is caused."194 This situation echoes the well-established concept of détournement de pouvoir (misuse of powers) in administrative law. Of course a difficulty arises in proving "intention." As noted by G.D.S. Taylor:

[The fact] that a person is tempted to act in bad faith or otherwise abuse his rights does not invalidate the action taken. The action is invalid only if the abuse was integral to the action taken and led to it in some way. The reasons for the action must be bad .... The necessary first step is to ascertain the decision-maker's reasons. He may actually state them, or, alternatively, his failure to state them may be an abuse of right .... $[\mathrm{W}]$ here the reasons are not stated they must be inferred from the surrounding facts. ${ }^{195}$

The PCIJ had further clarified in Certain German Interests in Polish Upper Silesia that any abuse of rights "cannot be presumed, and it rests with the party who states that there has been such misuse to prove its statement."196 Regardless of evidentiary difficulties, the situation introduces a basic necessity requirement whereby a country may only exercise its right to achieve a set of distinct aims and is banned from exercising it for unnecessary purposes, that is, purposes not recognized by the international community when formulating the very right.

The second situation concerns cases where Country A exercises a right in such a way that hinders Country B's ability to enjoy its own rights and, as a consequence, Country B suffers an injury. As an example, Kiss notes the "inconsiderate use of . . the radio-electronic spectrum," whereby one of the two states sharing the spectrum will feel a reduction in their

\footnotetext{
\begin{tabular}{lllllll}
\hline Int'l L. Comm'n & L, & U.N. & Doc. & A/CN.4/119 & (1959),
\end{tabular}

http://legal.un.org/ilc/documentation/english/a_cn4_119.pdf [https://perma.cc/6X8D-S479] (ILC Special Rapporteur Garcia-Amador noted that "both in the writings of publicists and in diplomatic and legal practice it has been recognized that international responsibility may also be incurred if a State causes injury through the 'abusive' exercise of a right; that is to say if it ignores the limitations to which State competence is necessarily subject and which are not always formulated in exactly defined and specific international obligations.") [hereinafter Garcia's Report].

193. Kiss, supra note 190, at 5. The third situation not addressed in this Article is that the arbitrary exercise of its rights by a State, causing injury to other States but without clearly violating their rights, can also amount to an abuse of right. Id.

194. Id.; see also Garcia's Report, supra note 192, at 8 (citing R. L. Bindschedler, La Protection de la Propriete Privee en Droit International Prive, in 90 RECUEIL DES COURS DE L'ACADEMIE DE CROIT INTERNATIONAL 212-13 (1958)) ("It is not difficult to understand why it was recently said that the 'arbitrary exercise of State competences and the use of juridical institutions for purposes alien to them are in fact abuse of rights."') (emphasis added).

195. G.D.S. Taylor, The Content of the Rule of Against Abuse of Rights in International Law, 46 BRIT. Y.B. INT’L L. 323, 331-32 (1972).

196. Certain German Interests in Polish Upper Silesia (Ger. v. Pol.), Judgment, 1926 P.C.I.J. (ser. A) No. 7, at 30 (May 25).
} 
enjoyment of the resource because of the behavior of the other State. ${ }^{197}$ In those situations, Kiss concludes, a "balance of interests" test should be introduced in such a way that abuses will only be found in cases "when the injury suffered by the aggrieved States exceeds the benefit resulting for another State from the enjoyment of its own right." 198 This is in essence a proportionality test.

Whenever abuse of rights is discussed, Lauterpacht's sobering words about the delicacy in its application often follows:

These are but modest beginnings of a doctrine which is full of potentialities and which places a considerable power, not devoid of a legislative character, in the hands of a judicial tribunal. There is no legal right, however well established, which could not, in some circumstances, be refused recognition on the ground that it has been abused. The doctrine of abuse of rights is therefore an instrument which ... must be wielded with studied restraint. ${ }^{199}$

These words are of course true, but as alluded the doctrine should be most used in cases where it "represents a plea for legislation or the modification of rules to suit special circumstances."200 Indeed, abuse of rights is a classic general principle in the sense that its primary function is to fill gaps and lacunas in the law and push forward the rule-making processes in our international system. Given that the law on espionage is one that is covered in a myriad of legal gaps, and that it is unlikely that a rule-based system can emerge organically through the drafting of a treaty or the evolution of custom, this field of inter-State activity becomes most ripe for filling through the use of general principles.

Applying the abuse of rights doctrine to the question of spying, it becomes clear that States may not utilize their right to spy for purposes other than advancing their national security and/or the peace and security of the international system as a whole. Utilizing one's surveillance arm for other purposes would fall squarely outside the derivative Hohfeldian limits ascribed to the right and would therefore result in an abuse. In recognizing the right to spy, the international community inexplicitly created a caveat to Articles 2(1), 2(4), and 2(7) of the U.N. Charter. Countries were willing to accept as tolerable injuries and assaults on territorial sovereignty, political independence, and the jurisdiction to determine domestic affairs, in the name of maintaining the important functions of intelligence in our public world order. So long as the surveillance serves the raison d'être of our public international system, the fundamental goals of all law: "the minimization of violence, the maintenance of minimum order, and as

197. Kiss, supra note 190 , at 5 .

198. Id.

199. Hersch LAuTERPACHT, THE DEVElopment OF INTERNATional LAW BY THE INTERNATIONAL COURT 164 (1958).

200. CRAWFORD, supra note 191 , at 562. 
approximate an achievement of the policies of human dignity as each situation allows," 201 the activity will be the stomached by the rest of the community. However, such interferences will no longer be tolerable if the state is abusing its right by either engaging in unnecessary or disproportionate surveillance activities. This puts into greater context Scott's notion that the ILI includes a set of "unexpressed but generally accepted norms and expectations."202

Finally, to return full circle, an act of maritime reconnaissance and surveillance would be seen as serving "peaceful purposes" and therefore constituting an "international lawful use" to the extent that the surveilling party is not abusing its right to spy by acting in an unnecessary or disproportionate manner. Intelligence gathering, however, can on occasion run in contrast with the international system's raison d'être. Like Orthrus, the two-headed dog of Geryon from Greek mythology, so is intelligence a unique dicephalic creature, each of its heads pushing in dyadic opposition. Political scientist Abram Shulsky and Gary Schmitt remarked upon this phenomenon: "Intelligence is concerned with that component of the struggle among nations that deals with information. As such, it has a dual nature, one part governed by the fact that it deals with information, the other part by the fact that it is part of the conflict among nations . . .."203

In his first State of the Union Address, President George Washington said that: "[t]o be prepared for war is one of the most effectual means of preserving peace." 204 Indeed, "[t]he key to the contemporary global security system is a reliable and unremitting flow of intelligence to the pinnacle elites." 205 When policy makers are provided with sufficiently accurate information as to the levels and types of threats posed by their adversaries, their intentions, and capabilities, they are more likely to

201. W. Michael Reisman, Editorial Comment: Assessing Claims to Revise the Laws of War, 97 AM. J. INT'L L. 82, 83 (2003); see also W. M. REISMAN, THE QUEST FOR WORLD ORDER AND HUMAN Dignity IN THE TWENTY-FIRST CENTURY: CONSTITUTIVE PROCESS AND INDIVIDUAL COMMITMENT 442-45 (2012). Reisman defines the principle of minimum order as the "sine qua non for all other goals" in our legal system. Id. at 442. On the basis of this principle we may appraise "past and prospective arrangements and prospective decisions concerning security, not in terms of the interests of a single participant or group of participants but in terms of everyone's security." Id. at 443 (emphasis in original). Minimum order entails both "a low expectation of violence" as well as the "avoidance of surplus violence." Id. at 442, 445 (emphasis in original).

202. Roger D. Scott, Territorially Intrusive Intelligence Collection and International Law, 46 A.F. L. REV. 217, 226 (1999) ("As long as unexpressed but generally accepted norms and expectations associated with espionage are observed, international law tolerates the collection of intelligence .....").

203. ABRAM N. SHULSKY \& GARY J. SCHMITT, SILENT WARFARE: UnDERSTANDING THE WORLD OF INTELLIGENCE 177 (1991) (emphasis added). Differently put by Professor Der Derian: "The same satellite that monitors and helps us verify whether the Soviets are conforming to the INF treaty, simultaneously maps the way for low-level, terrain-following cruise missiles." James Der Derian, AntiDiplomacy, Intelligence Theory and Surveillance, in ESPIONAGE: PAST, PRESENT, FUTURE? 43 (Wesley K. Wark ed., 1994).

204. President George Washington, First Message to Congress on the State of the Union (Jan. 8, 1790)

205. McDougal, Lasswell, \& Reisman, supra note 184, at 434 
calibrate their responses properly, and are less likely to rely on force as a means for guarding against startling attacks or strategic surprises. ${ }^{206}$ Intelligence gathering in this context serves a stability-enhancing function in public world order, by increasing the potential for pacific settlement of disputes and reducing the chances for violence. ${ }^{207}$ We have seen this function of intelligence play out in the context of the EEZ many times. Within the zone, "there are many intelligence gathering activities that are part of arms control verification agreements and serve a critical role in confidence building and thus peacekeeping."208 Similarly, even if some of the surveillance operations are used to gain advantage over other States, those activities could still be viewed as a "force for peace because it acts as a deterrent."209 Furthermore, Lt. Col. Andrew Williams of the U.S. Navy has contended that "[t]hrough aerial reconnaissance, the international community may refine its strategic assessment of a country and acquire a better understanding of the threat it may pose. The collection of intelligence can protect against surprise attack and reduce tension." 210

Espionage is itself, however, is a kind of act of betrayal, and is thus a "double-edged sword." 211 While the collection of intelligence may help

206. James E. Baker, former Chief Judge to the United States Court of Appeals for the Armed Forces, summarized Professor Reisman's work in the field of intelligence:

Three goals of intelligence are emphasized. The first goal is for intelligence to inform decision, which improves decision. . . .

The second goal is for intelligence to offer a source of stability in maintaining international public order. A state that collects intelligence regarding intent and capacity may be less likely to misread or misapprehend the ambiguous conduct of a potential adversary. . . .

The third goal is for intelligence to serve the interests of stability and security by offering a means to prevent surprise.

James E. Baker, Prelude to Decision: Michael Reisman, the Intelligence Function, and a Scholar's Study of Intelligence in Law, Process, and Values, in LOOKING TO THE FUTURE: ESSAYS ON INTERNATIONAL LAW IN HONOR OF W. MiChaEl REISMAN 76 (Mahnoush H. Arsanjani et al. eds., 2011).

207. Michael Herman, Ethics and Intelligence after September 2001, in 2 ETHICS OF SPYING: A READER FOR THE INTELLIGENCE PROFESSIONAL 106 (Jan Goldman ed., 2010) (“[G]overnments drawing on a professional standard of intelligence knowledge tended to behave as more responsible members of international society than those that had to manage without it, or chose to do so .... This was a general effect, though specific cases could also be adduced in which intelligence had been deliberately used to underpin specific stability-producing conflict reduction arrangements, as in arms control or some of the U.S. mediation efforts ....").

208. Summary of the Bali Dialogue, supra note 16, at 17.

209. Id.

210. Williams, supra note 52, at 59-60 (citations omitted) ("Information about the coastal state collected from the EEZ can apprise neighbors and interested states about the coastal state's ambitions or potential to threaten the region or beyond. Additionally, the UN Security Council, which is responsible for maintaining international peace and security, does not have its own intelligence service. It depends on information it receives from UN member states. Yet new threats to international peace and security continue to arise, including from a number of coastal states, especially states that are secretive and closed. Recent examples of coastal states with programs that pose grave concern to other states include the Democratic People's Republic of Korea and the Islamic Republic of Iran. North Korea recently conducted a second nuclear test in defiance of UN Security Council resolutions. This test came shortly after North Korea launched from within its territory a long-range rocket, also in defiance of UN Security Council resolutions. Additionally, the Islamic Republic of Iran is reportedly developing a nuclear weapons program and is itself the subject of several UN Security Council resolutions. Without reliable information, the UN Security Council cannot reach agreement on appropriate and effective collective action to respond to threats.").

211. Tony Pfaff, Bungee Jumping off the Moral Highrround: Ethics of Espionage in the Modern 
defuse conflicts over the long haul, its immediate effect is the signaling of "distrust and suspicion," which "rather than fostering peace and security, fosters instability and conflict." 212 This is particularly true when the collection efforts are conducted in ways that are perceived as illegitimate, either because of their basis of justification or choice of means. In these scenarios, intelligence agencies would seem to be employed not in the name of a Washingtonian "preservation of peace," but rather in the service of the "continuation of war by the clandestine interference of one power into the affairs of another power." 213

Stuck between these two heads of the intelligence Orthrus, it would seem that we are presented with a broad spectrum of potential activities that would have to be examined on a contextual basis (one which considers the particular circumstances of each surveillance operation, its goals, and the means employed). ${ }^{214}$ The issue is therefore not with the maritime zone from within which the spying takes place, but rather the specific facts surrounding each spying operation. This has surely been the position of McDougal, Lasswell, and Reisman, who have argued that the "gathering of intelligence within territorial confines of another state is not, in and of itself, contrary to international law unless it contravenes policies of the world constitutive process." 215 What is therefore missing from the literature is a precise and careful drawing of the broader ILI lines (as opposed to the EEZ lines) so as to define the boundaries of accepted behavior. Intelligence gathering "ranges widely from forcible to non-forcible interventions; from purely analytical to violently 'wet work;' and from overtly persuasive to covertly manipulative forms of influence." 216

In the context of surveillance within the EEZ, a growing number of commentators have predicted an increase in violence and political tension as a result of the rise of electronic and cyber warfare capabilities: ${ }^{217}$

[I]ntelligence gathering activities in EEZs are most likely going to become more controversial and more dangerous. In Asia, this disturbing prospect reflects the increasing and changing demands for technical intelligence; the robust weapons acquisition programs, especially increasing electronic warfare (EW) capabilities; and the widespread development of information warfare capabilities. Further, the scale and scope of maritime and airborne intelligence collection activities are likely

\footnotetext{
Age, in 1 Ethics of SPying: A REAdER fOR the InTELligenCe Professional 66, 76 (Jan Goldman ed., 2006).

212. Id.; see also Glenn Hastedt, Espionage: A Reference HandBooK 48 (2003) ("The starting point for overcoming uncertainty and increasing the predictability of the actions of other states is the acquisition of information about them. Espionage is a means of doing so, but given the deceit and potentially treasonous nature of the act, it is also one surrounded by ambivalence.").

213. James Der Derian, ANTIDIPLOMACY: SPIES, TERror, SPEED AND WAR 21 (1992).

214. Id.

215. McDougal, Lasswell, \& Reisman, supra note 184, at 395.

216. DERIAN, supra note 213 , at 21.

217. See generally supra note 9 and accompanying text.
} 
to expand rapidly over the next decade, involving levels and sorts of activities quite unprecedented in peacetime. They will not only become more intensive; they will generally be more intrusive. They will generate tensions and more frequent crises; they will produce defensive reactions and escalatory dynamics; and they will lead to less stability in the most affected regions, especially in Asia. ${ }^{218}$

Another commentator had suggested that the threat is most worrisome in the East-China Sea, further noting that:

The frequent visit by foreign naval survey vessels and routine flight of military intelligence planes over the EEZs of the coastal States in the region certainly represents a major source of tension and instability. There is all the likelihood for them to cause surface and air traffic control problems, and increase the chances of accidents, if not conflicts. Countries subject to these intrusive navigation and over-flight off their coastal waters are likely if not inevitably to take counter-measures to safeguard their maritime jurisdiction and interests. ${ }^{219}$

These considerations must be borne in mind as we develop a forwardlooking, minimum-order-based, set of tests that would help determine the limits of the right to spy. The standards introduced in Section IV aim to do just that, as their goal is to serve a useful compass to determine what would a priori constitute serving "peaceful purposes" and what would prima facie constitute a potential abuse of rights.

\section{B. On Surveillance Capabilities, Technological Advancements, and the Evolutionary Interpretation of Treaties}

The dichotomy between law and technology has long been tenuous in the best of times, and irreconcilable at the worst. Answering to different masters, technological development and legal structures are in a constant state of ebb and flow, with each pushing the contours of the other in choreographed exchange of concessions and compromises. ${ }^{220}$

One way that has been proposed to secure a permanent dance floor on which law and technology could share their "choreographed exchange" is through the evolutionary interoperation of treaties. The ICJ had recently addressed the issue in dicta in its Navigational and Related Rights (Costa Rica v. Nicaragua) judgment:

[T] here are situations in which the parties' intent upon conclusion of the treaty was, or may be presumed to have been, to give the terms used- or some of them- a meaning or content capable of evolving, not one fixed once and for all, so as to make allowance for, among other things, developments in international law. In such instances it is indeed in order to respect the parties' common intention at the time the treaty was

218. Mark J. Valencia \& Kazumine Akimoto, Report of the Tokyo Meeting and Progress to Date, 29 MARINE POL'Y 101, 102-03 (2005).

219. Gao, supra note 53, at 291.

220. Timothy Coughlin, The Future of Robotic Weaponry and the Law of Armed Conflict: Irreconcilable Differences?, 17 UCL JURIS. REV. 67, 67-68 (2011). 
concluded, not to depart from it, that account should be taken of the meaning acquired by the terms in question upon each occasion on which the treaty is to be applied ... where the parties have used generic terms in a treaty, the parties necessarily having been aware that the meaning of the terms was likely to evolve over time, and where the treaty has been entered into for a very long period or is "of continuing duration," the parties must be presumed, as a general rule, to have intended those terms to have an evolving meaning 221

This position of the Court is not new, however. Judge Jessup had said in his dissenting opinion to the South West Africa Cases as early as 1966 (and shortly after the adoption of the Vienna Convention on the Law of Treaties) that: "The law can never be oblivious to the changes in life, circumstance and community standards in which it functions. Treatiesespecially multipartite treaties of a constitutional or legislative charactercannot have an absolutely immutable character." 222

UNCLOS, coined by some as the Constitution of the Sea, relies heavily on "generic terms" (some of which we have already encountered in this survey, such as "international lawful use," "peaceful purposes," "due regard," "marine scientific research," and "equity"). Given the significant political and technological advancements that have occurred since the formulation of the treaty, there is room to argue in favor of a reading of these terms that is influenced by these dramatic tectonic shifts. ${ }^{223}$ What an "international lawful use" might have meant under a Cold War mentality in 1982 could mean something utterly different in 2018 , in a multi-polarized international political system with increased types and levels of threats and broader needs for securitization. ${ }^{224}$ Current inadequacies within the EEZ regime, therefore, could be corrected through a process of interpretative

221. Dispute Regarding Navigational and Related Rights (Costa Rica v. Nicar.), Judgment, 2009 I.C.J. 213, 242-43 (Jul. 13) (emphasis added); see also Aegean Sea Continental Shelf (Greece v. Turk.), Judgment, 1978 I.C.J. 3, 32 (Dec. 19).

222. South West Africa Case (Eth. v. S. Afr.), Second Phase Judgment, Dissenting Opinion of Judge Jessup, ICJ Rep 1966, 439 (Jul. 18).

223. Gao, supra note 53, at 292-93 ("All these recent developments demonstrate that the LOS Convention as the Charter of the world oceans, is not squarely perfect. And they also suggest that some of the provisions in the Convention, formulated some [thirty-five] years ago in a very different political and technological context, be revisited in the light of the new circumstances such as that of the PostCold War and the '9/11' terrorist attacks."); see also Guifang, supra note 9, at 89 ("The advancement of science and technology requires adjustments in state practice regarding appropriate interpretation of provisions of the United Nations Convention on the Law of the Sea (UNCLOS) in order to address current inadequacies in the international framework.").

224. See, e.g., Wachman, supra note 20, at 117 ("During the Cold War, the cat-and-mouse, tit-fortat, thrust-and-parry competition with the Soviet Union was a rivalry between two more or less evenly matched opponents. Applying the same norms and harboring expectations that its relations with the PRC ought to follow the same pattern, Washington either overlooks or revels in the asymmetry."); Haiwen, supra note 93, at 39 ("[The U.S.-Soviet dealings] happened in the Cold War era and [are] the product of the Cold War confrontation between the two superpowers at that time. As we all know, the present relationship between China and the United States is obviously not one between Cold War opponents or one of any confrontation; both China and the United States reaffirmed their commitment to building active cooperation in the twenty-first century and to taking concrete actions to deal with common challenges to establish a steady partnership."). 
reevaluation of these terms under UNCLOS. ${ }^{225}$

We have already witnessed one example of this evolutionary interoperation in the context of Chinese prohibitionist positions with regards to MSR. ${ }^{226}$ Scholars had argued that the introduction of the GPS has completely redefined hydrographic surveying, justifying a need for a reexamination of the meaning of MSR under UNCLOS. ${ }^{227}$ However, another provision of UNCLOS that is perhaps ripe for an evolutionary interpretation is Article 19(2)(c), which concerns innocent passage in the territorial sea. The provision is important because it is the only one in the treaty to speak in some fashion about espionage. In fact, it is the only treaty provision globally which uses negative language in speaking explicitly about the practice of espionage. Under UNCLOS, ships of all States enjoy the right of innocent passage through the territorial sea. ${ }^{228}$ Article 19 establishes "passage is innocent so long as it is not prejudicial to the peace, good order or security of the coastal State." The Article proceeds by establishing a set of circumstances that prima facie are to be considered as prejudicial to peace, good order or security; one of them is Article 19(2)(c), which speaks of "any act aimed at collecting information to the prejudice of the defence or security of the coastal state."

Since the drafting of UNCLOS, surveillance technology has evolved significantly. Reconnaissance activities now conducted in the EEZ are comparable to those that used to be conducted in the territorial sea and for which legal presumptions and protections were found necessary by the drafters of UNCLOS. It begs the question: why should legal protections not be granted in the EEZ against the same exact intelligence activities which the drafters found useful to deem prima facie prejudicial to peace, order, and security under Article 19(2)(c)? ${ }^{229}$ This question is further heightened when one compares the types and volumes of threats that exist today in the sphere of marine security with what existed at the time when UNCLOS was drafted. The rising securitization of the oceans is a knee-jerk reaction to this rise in threats and their sophistication. While not all aspects of this phenomenon should be condoned, some of its root causes and logic should nonetheless be acknowledged.

225. KLEIN, supra note 40, at 221 ("The current legal position appears to support the legality of intelligence gathering by third states in the EEZ. Is this desirable, though? A change may be warranted in light of the international tension created through intelligence gathering activities in the EEZ, most clearly evidenced in the encounters between China and the United States, and the increasing securitization of the EEZ . . . . Modern means of warfare, especially the use of information warfare and electronic warfare, support an argument that the position should shift to prevent intelligence gathering in another State's EEZ.").

226. See supra Section II.B.1.a

227. See supra notes $119-120$ and accompanying text.

228. UNCLOS, supra note 11, art. 17.

229. KLEIN, supra note 40, at 220; see also Ren Ziafeng \& Cheng Xizhong, A Chinese Perspective, 29 MARINE POL'Y 139, 143-45 (2005). 
At the same time, even if we recognize Article 19(2)(c)'s place in the broader law of the sea regime, and even if we extend its logic to the EEZ through a form of evolutionary interpretation, we must nonetheless apply it through the lenses of the lex specialis of the ILI. We should determine which practices of surveillance should be tolerated in accordance with the standards on the right to spy as above illustrated.

McDougal, Lasswell, and Miller had argued in 1967 that treaty interpretation must give due effect to "basic constitutive policies of the larger community," to the "requirements of fundamental community policy," and to "the goals of public order." 230 This reference to community values and minimum order in treaty interpretation seems to echo Judge Jessup's position in the South West Africa case and the Court's dicta in Costa Rica v. Nicaragua. In the context of UNCLOS, they would all seem to favor a broader review of treaty obligations, which considers, on a caseby-case basis, the impacts that technology has had on intelligence collection within the zone.

$* * *$

Section III of this paper looked at both the unique nature of the right to spy within the ILI and the limitations imposed on that right. Section III additionally examined the way in which advancements in the field of maritime surveillance might justify a technology-induced evolutionary interpretation of UNCLOS. What is clear from both the analyses is that the use of certain surveillance capabilities, for certain purposes, in certain fashion, from within or above the EEZ might indeed erode and subvert the international equilibrium that has been struck within the ILI in relation to UNCLOS. Section IV thus introduces three possible limitations on intelligence collection, as an attempt to respond to the modern demands discussed above.

\section{TAMING THE DRAGON-KINGS WITH LEGAL HOOPS}

Scholarly proposals for the rebalancing of rights and obligations amongst maritime and coastal States are not new. Professor Potter had suggested as early as 1927 that:

[L]itoral states may act in certain ways for the preservation of their safety and the protection of their laws over an undefined and indefinite stretch of coastal waters .... Real danger to the littoral state or its laws, and actual infractions of those laws, are the tests of the right of the state to act, rather than the scene of that action. ${ }^{231}$

230. Myres McDougal, Harold Lasswell, \& James Miller, The Interpretation of INTERNATIONAL AGREEMENTS AND WORLD PUBLIC ORDER 41-44 (1967).

231. Pitman B. Potter, The Freedom of the Seas in History, Law and Politics 103-04 
Professor Lissitzyn was the first to propose, as early as 1970 and long before the codification of the EEZ regime, the setting of certain limitations on States' reconnaissance operations on the high seas (even within the global commons): 232

Although international law does not forbid electronic reconnaissance from the high seas and does not empower the coastal state to interfere with foreign warships and aircraft engaged in it, such reconnaissance is likely to be resented by coastal states and to heighten international tensions. It should be resorted to, therefore, only if careful study indicates that its costs are substantially outweighed by its benefits to the state that engages in it. ${ }^{233}$

Lissitzyn's proposal for a cost-benefit study to be taken by States prior to their unilateral initiation of maritime electronic reconnaissance operations is a fascinating one, not only for its intuitive clairvoyance. First, Lissitzyn makes clear that this proposal falls outside the ambit of the lawin-existence, the lex lata. Nonetheless, he puts forward his proposal as a matter of lex ferenda, or future-law. The proposal is introduced as a suggested operative guideline to be internalized by States, arguably, as a first step towards broader regulation.

Furthermore, Lisstizyn is grounding this legal move on the basis of minimum order justifications (noting that the existing conscripted structure is only likely to "heighten international tensions"). This is intriguing, given the fact that Lissitzyn is applying his proposed model to the high seas at a time where flag States possessed only limited technological capacities in the field of maritime reconnaissance. Just imagine if Lissitzyn were to live in our times. Surely, upon examination of the EEZ surveillance problem, he would welcome the application of a similar, if not higher, standard within the zone, where (unlike the high seas) coastal States enjoy at least partial sovereign territorial rights, and are increasingly exposed to more intrusive potential surveillance capabilities as well as maritime threats. Moreover, Lisstizyn's approach follows a similar thinking to the one that I put forward whereby we base our analysis of tolerated acts of espionage not on the basis of their specific location, but on a contextual analysis of the reasons for spying and the means employed.

Finally, the proposal is unique as it suggests a cost-benefit study for determining the prudence of a particular electronic reconnaissance operation, thus echoing the language of necessity and proportionality as above discussed.

(1924).

232. Lissitzyn, supra note 91 , at 569 ("Although international law does not forbid electronic reconnaissance from the high seas and does not empower the coastal state to interfere with foreign warships and aircraft engaged in it, such reconnaissance is likely to be resented by coastal states and to heighten international tensions. It should be resorted to, therefore, only if careful study indicates that its costs are substantially outweighed by its benefits to the state that engages in it.").

233. Id. 
Post-UNCLOS scholars and research institutes have too suggested certain limitations and mechanisms for governing intelligence collection within the zone. In this context one should note Oxman (1984), ${ }^{234}$ and to a greater extent Beckman and Davenport (2012), who had suggested separately a "due regard" model as a limit to certain military and reconnaissance activities within the zone, and as a potential obligation setter for flag States to negotiate and notify prior to launching a unilateral surveillance activity. ${ }^{235}$ Other proposals include Kaye's (2005) examination of the subjective intentions of flag States in determining the lawfulness of their intelligence activity ${ }^{236}$ and Hayashi's (2005) reference to a reasonableness standard as a possible limitation. ${ }^{237}$

The most robust guidelines so far suggested are those put forward by EEZ Group 21, an initiative of the Ocean Policy Research Foundation in Japan, which included senior officials, legal experts, and maritime specialists. The guidelines set clear definitions to UNCLOS terms that were previously left undefined (namely "peaceful uses/purpose," "military surveys," "military activities," "marine scientific research," and "hydrographic survey"). Furthermore, the guidelines introduce two very pertinent limitations on intelligence gathering by third States within and above the zone. First, in Article V.b., the group suggests that:

"Ships and aircrafts of a State undertaking military activities in the EEZ of another State have the obligation to use the ocean for peaceful purposes only, and to refrain from the threat or use of force, or

234. Bernard H. Oxman, The Regime of Warships Under the United Nations Convention on the Law of the Sea, 24 VA. J. INT'L L. 809, 878 (1984) ("It is essentially futile exercise to engage in speculation as to whether naval maneuvers and exercises within the economic zone are permissible. In principle they are. States simply never agreed to abandon such rights in all the semi-enclosed seas of the world, including all those bordering Europe and Arabia, for example. The relevant inquiry is whether the particular activity in a particular place is consistent with the 'due regard' obligation. For example, it would be difficult to justify weapons exercise that does significant damage to a valuable natural resource being exploited by the coastal State in the economic zone. On the other hand, a coastal State's political or military interest in avoiding the presence of the warship is not in itself reflected in its economic zone rights under article 56, and accordingly is not an object of the "due regard' obligation of the flag State.").

235. Beckman \& Davenport, supra note 13, at 23-24, 29 ("The first course of action would be a good faith observance (required by Article 300) of the mutual obligations of 'due regard' in the EEZ. From a practical perspective, this should involve procedural steps of consultation, notification and cooperation to minimize interference with each other's legitimate rights in the EEZ . ... Implementation of the 'due regard' obligation through notification or consultation ... may not be a feasible solution particularly when it comes to intelligence-gathering survey activities. One way to deal with this issue is for the surveying State to assure the coastal State that the information being gathered is only for military purposes and that the information will not be made available to the public.").

236. Kaye, supra note 7, at 100-02 ("If the case for freedom to undertake military surveillance in another State's EEZ can be made, it is clearly subject to some qualification .... One issue that could be relevant in assessing the legality of military surveillance from the EEZ, or high seas, relates to whether such surveillance might constitute a threat to international peace and security... routine intelligence-gathering flights or voyages through another state's EEZ would not of themselves be illegal, unless they formed a prelude to an unauthorised attack on another state.").

237. Hayashi, supra note 8, at 129 ("It must be concluded from the foregoing that State practice and commentators are divided on whether military maneuvers, and particularly those involving use of weapons, in the EEZ of a foreign State without its consent are internationally lawful uses of the sea .... Commentators tend to argue that naval exercises of reasonable scale without the use of weapons are permitted."). 
provocative acts, such as stimulating or exciting the defensive systems of the coastal State; collecting information to support the use of force against the coastal State . . .."238

Furthermore, in Article VI.a., it is suggested that: "The activities of another State in the EEZ of a coastal State should not interfere with the communications, computer, and electronic systems of the coastal State, or make broadcasts that adversely affect the defense or security of the coastal State." 239 While there is no indication that any State has adopted these guidelines, they nonetheless offer an interesting alternative comprehensive resolution for the EEZ debate.

More broadly, it is the author's contention that there exists a connecting thread between all of the scholarly proposals suggested above. They all seem to echo certain aspects of necessity and proportionality and would also correlate with the author's description of the right to spy and the ways by which it might be abused. Necessity, Last Resort, and Proportionality are a set of legal "yardsticks" 240 developed over time through customary evolution to constrain the lawful behavior of intrastate engagement. ${ }^{241}$ For example, while the U.N. security system allows for the unilateral use of force by States to tackle unlawful force mounted against them, international law puts in place jus ad bellum limitations to ensure that no abuse occurs in the exercise of this right. ${ }^{242}$ This is done to manage the potential pitfalls of codifying a lawful recourse to self-help by States.

Unilateral intelligence gathering is not thematically different from unilateral uses of force, and in many ways it is also a reflection of a primitive system structured around self-help. If we wish to recognize unilateral intelligence activities by States as lawful (or at the very least tolerable), because we contend that they serve the function of maintaining both national security and international peace and stability, we must also accept certain limitations so to prevent potential misuse and abuse of this right. We need to ensure that Dr. Jekyll does not turn into Mr. Hyde. This Section is interested in identifying what such limitations might look like in the context of intelligence gathering within and above the EEZ, while applying them to actual recent cases.

238. Sam Bateman, Prospective Guidelines for Navigation and Overflight in the Exclusive Economic Zone, 144 MAR. STUDS. 17 Annex B (2005) (emphasis added).

239. Id.

240. Yoram Dinstein, WAR, AgGRession AND SELF-Defense 231 (5 $5^{\text {th }}$ ed., 2012).

241. See generally NoAm Lubell, Extraterritorial USE OF Force Against Non-State ACTORS 43 (2010); see also Legality of the Threat or Use of Nuclear Weapons, Advisory Opinion, 1996 I.C.J. $\uparrow 4$ (Jul. 8), (recognizing necessity and proportionality rules of customary international law).

242. DINSTEIN, supra note 240 , at 187 ("[T]he essence of self-defense is self-help: under certain conditions set by international law, a State acting unilaterally - perhaps in association with other countries - may respond with lawful force to unlawful force (or, according to some, to the imminent threat of unlawful force). The reliance on self-help as a remedy available to States when their rights are violated, is and always has been one of the hallmarks of international law. Self-help is a characteristic feature of all primitive legal systems, but in international law it has been honed to art form.”). 


\section{A. Necessity and Just Cause}

As discussed above, the legal (not to say moral) ${ }^{243}$ justification for the practice of surveillance is that such practice must serve the justifications that stand at the heart of the right to engage in espionage in the first place. Borrowing from Just War doctrine, intelligence operations within and above the zone must entertain a "just cause." As further suggested by Professor Genderon:

Just Cause with respect to the use of intelligence requires that the need to know ... [be] deemed necessary to identify, clarify, prevent, or counter real and certain threats to ensure national security. The claim must be real and not spurious, and capable of being demonstrated as such within oversight procedures. 244

A submarine spying on a coastal State to determine whether it conducted an otherwise non-acknowledged nuclear test, or a marine vessel engaging in a reconnaissance mission off the shores of a particular foe to map out missile sites, would surely meet the necessity requirement. Put differently, operations would be deemed necessary if they serve either the national security interests of the State or the minimum order goals of our public world order (the minimization of violence and the increase of stability across the system).

On the other hand, applying Genderon's approach to the EEZ issue would seem to entail that surveillance operations which are employed as a coercive political tool would not be deemed necessary. Consider, for example, the U.S. FONOP program. The program involves the sending of warships and surveillance vessels into both the 200 nautical-mile EEZ and the twelve nautical-mile territorial seas of coastal States. The FONOP program, which has been ongoing since the late ' 70 s and early ' $80 \mathrm{~s}$, is designed "to challenge maritime claims that the U.S. finds inconsistent with international law. These operations 'involve naval units transiting disputed areas to avoid setting the precedent that the international community has accepted these unlawful claims." 245 In other words, the United States is

243. See Pfaff, supra note 211, at 98 ("[T] profession, particularly where such practices involve committing acts that would be immoral outside the professional context, is that such acts must aim at promoting national security, not simply national interests, and especially not simply the interests of some nationals.").

244. Angela Gendron, Just War, Just Intelligence: An Ethical Framework for Foreign Espionage, 18(3) INT'L J. INTELLIGENCE \& COUNTERINTELLIGENCE 398, 417-18 (2005)

245. Testimony of the Director of South Asia Programs, supra note 156, at 3; see also O'RouRKE, supra note 18, at 28; Julian Ku, Dear World Media: The U.S. is NOT Challenging China's Territorial Claims in the South China Sea (Yet), OPINIO JuRIS (May 27, 2015), www.opiniojuris.org/2015/05/27/dear-world-media-the-u-s-is-not-challenging-chinas-territorialclaims-in-the-south-china-sea-yet/ [https://perma.cc/WX8D-2THN]; LYNN KUOK, THE U.S. FON Program In THE SOUTH CHINA SEA: A LAWFul AND NECESSARY RESPONSE TO CHINA's STRATEGIC AMBIGUITY (2016) (“Under UNCLOS, 'freedom of navigation' refers (only) to navigation rights user states enjoy in the exclusive economic zone (EEZ) and high seas, subject to the obligation to pay 'due regard' to the rights and duties of the coastal states and to comply with the laws and regulations adopted by the coastal state in accordance with UNCLOS .... In addition, the FON Program also guards against 
employing parts of its naval reconnaissance arm, not to collect necessary intelligence against an adversary, but rather as a new form of rattlediplomacy and lawfare, ${ }^{246}$ which only increases tension and decreases cooperation. At the heart of the FONOP program stands the desire to "demonstrate a non-acquiescence to excessive maritime claims," 247 and it is further rooted in the fear that "a minority position could gather enough momentum to bring about establishment of a new law of the sea norm or "paradigm shift"' (with the legal basis for this concern being Article 31(3)(b) of the Vienna Convention on the Law of Treaties which considers subsequent practice in the application of treaties during treaty interoperation). ${ }^{248}$

International law provides States with numerous alternative avenues and forums to make their legal positions heard and prevent their acquiescence to certain claims by other States. Reliance on stabilitythwarting self-help operations solely for the purpose of making a legal point against the PRC would run counter to the purposes for which the right to spy was intended. Moreover, and this is the key point, even under the author's proposal, the U.S. should be able to continue to engage in surveillance operations in the South China Sea when those operations meet standards of necessity and proportionality. Those operations could in and of themselves serve the purpose of non-acquiescence which the United States is headstrong in achieving. Nonetheless, the volume of the operations will decrease to what the United States identifies as important, and thus stability will increase as a result. ${ }^{249}$

On the other side, consider China's surveillance operations across the South China Sea. The Annex VII Tribunal in the South China Sea Arbitration found in its 2016 award a violation of the law of the sea by China's utilizing of its surveillance vessels for the purposes of advancing its "creeping jurisdiction." 250 Another example could be China's

claims inconsistent with the legal divisions of the ocean and related airspace reflected in UNCLOS since excessive maritime claims in these respects will reduce navigation and overflight rights.").

246. MAJ Chuah Meng Soon, supra note 97 (making the case for FON operations and concluding by saying that "lawfare will continue in the debate of UNCLOS between maritime powers and coastal states").

247. U.S. DEP'T OF DEF., "Freedom of Navigation Program: Fact Sheet", 1 (March 2015), http://policy.defense.gov/Portals/11/Documents/gsa/cwmd/DoD\%20FON\%20Program\%20--

\%20Fact\%20Sheet\%20(March\%202015).pdf [https://perma.cc/4F7H-YLRR].

248. KUOK, supra note 245 , at 4.

249. See GOLDSTEIN, supra note 80, at 287 ("These factors suggest that a move to placate Chinese concerns could reap major dividends for both regional and global security. From Washington's perspective, the legal principle that military activities are permissible within EEZs simply cannot be negotiable. However, standing firm on the principle does not preclude significant reductions in these activities, which hold the potential to seriously improve the security relationship.").

250. South China Sea Arbitration (Phil. v. China), Case No. 2013-19, Award, at 9757 (Perm. Ct. Arb. 2016), https://www.pcacases.com/web/sendAttach/2086 [https://perma.cc/SA6U-ZRV9]. The Tribunal argued that the decision by China to send maritime vessels into the Philippines' EEZ for the purpose of escorting fishing vessels which were deemed to be fishing illegally in those waters constituted a violation of the law of the sea. Id. ("China has, through the operation of its marine surveillance vessels 
surveillance in Japan's declared EEZ. ${ }^{251}$ Once again, it is argued that to rely on intelligence vessels and aircraft, not for their intended use, but rather as means for exerting authority or advancing legal and political interests through the subordination of the interests of other States, should be deemed an illegitimate use. China has multiple non-coercive means to challenge disputed maritime delimitations. Participating in arbitral proceedings is certainly one such option. Accepting as lawful an exploitive use of the intelligence function would provide a disservice for the function intelligence plays in international relations.

Finally, intelligence gathering cannot be used as a lawful countermeasure. Countermeasures are "limited by the requirements of humanity and the rules of good faith applicable in relations between States." 252 A State therefore cannot conduct surveillance operations in another State's EEZ, when the purpose is only to retaliate to what it perceives as a previous wrong. In this context, for Russia to rely on an aerial and naval "brinkmanship" policy, ${ }^{253}$ turning its reconnaissance vessels and aircraft into weapons in a political power-play over the Ukraine, is too destabilizing and illegitimate.

Professors McDougal, Lasswell, \& Reisman have suggested as early as 1973 that the "coercion level of intelligence gathering activities" should play a role in determining the lawfulness of the operation, but only within a broader contextual goal-sensitive analysis which will consider coercion alongside "all other facets of the case." 254 For the author, in determining the necessity of a particular surveillance operation, its coercive nondefensive nature must play an important determinative role. The above three examples, when read in context, and when considered in light of world order policy goals they are aimed to achieve, fall outside the lines of what is legitimately "necessary." They all reflect a reliance on the right to spy, but not for the purposes of which it was intended, and should therefore be branded as "abuse of rights." Such measures cannot be reconciled with UNCLOS Article 88's requirement of "peaceful purposes," or with broader international community interests as discussed in this Article.

As a final note, it should be made clear that if the intelligence operation crosses from a mere defensive or passive act to one with an offensive character (either if intelligence is collected to launch an immediate

in tolerating and failing to exercise due diligence to prevent fishing by Chinese flagged vessels at Mischief Reef and Second Thomas Shoal in May 2013, failed to exhibit due regard to the Philippines' sovereign rights with respect to fisheries in the Exclusive Economic Zone.”).

251. See supra note 93 and accompanying text.

252. Responsibility of Germany for Damage Caused in the Portuguese Colonies in the South of Africa (Port. v. Ger.), 2 R.I.A.A. 1011, 1026 (1928); Int'1 Law Comm'n, Rep. on the Work of Its FiftyThird Session, U.N. Doc. A/56/10, art. 50(a)(1) (2001).

253. See Frear, Kulesa, \& Kearns, supra note 150 and accompanying text.

254. McDougal, Lasswell, \& Reisman, supra note 184, at 419. 
offensive non-Charter-authorized attack, or if the operation takes the form of active electronic and information warfare activity), there would be even more reason to claim that such operations should be deemed unlawful as they constitute a threat or use of force in violation of Article 2(4).

\section{B. Immediacy/Last Resort}

Immediacy is directly tied to the principle of last resort. ${ }^{255}$ This would denote that a State contemplating a unilateral surveillance activity within a coastal State's EEZ should need to first satisfy itself, relying on verifiable evidence, that no alternative means were available for it to achieve its lawful objectives. As suggested by Professor Genderon:

The aim should be to limit use of the most intrusive collection means to those situations where, as a necessary and last resort, no alternative is possible, either because [alternative] sources are not available, or are likely to prove insufficient, unreliable, or incapable of producing what is required within the necessary time frame. ${ }^{256}$

In the context of maritime surveillance, applying this standard would entail, for example, that if the possibility exists to conduct the same operation, with the same results, from the high seas or outer space, such recourse will be mandated.

Similarly, if the option is viable to negotiate with the coastal State or provide some form of prior notification or reassurance, these too should be first exhausted. This is particularly true when operations are conducted in the name of tackling regional or international threats, such as drug trafficking, terrorism, or piracy. The MSR model enshrined in UNCLOS Article 246 should be applied here mutatis mutandis. In other words, the coastal State should generally grant consent for such surveillance operations, so long as "normal circumstances" persist. ${ }^{257}$ In this regard, consider the Peruvian attack on a U.S. propeller-driven C-130 aircraft on April 25, 1992, or the 2007 and 2009 Russian reconnaissance activities above the EEZs of Norway, Canada, and the U.K. If the United States was indeed conducting routine counterdrug surveillance missions, and Russia was indeed patrolling the seas and air to protect shipping lanes, there would be no reason for both these maritime powers not to seek the cooperation of the coastal States in whose EEZs they operated, or to the very least inform those States prior to the launching of unilateral operations. Not doing so increases suspicion and volatility and hampers both the operation's immediate success and, more broadly, intelligence as an international tool

255. Letter from Secretary of State Webster to British Minister Fox (1841), in 2 JOHN BASSETT MoORE, A DigeST OF INTERNATIONAL LAW 412 (1906) ("leaving no choice of means and no moment for deliberation").

256. Gendron, supra note 244 , at 418.

257. See supra notes 58-60 and accompanying text. 
for increasing cooperation in the long haul.

Going back to U.S. surveillance operations in the South China Sea as part of the FONOP program, one commentator has noted that "the United States could feasibly obtain the necessary surveillance data through other means, such as satellite reconnaissance and other less blatant intrusions." 258 This too should be taken into account in deciding if and which FONOP operations to launch.

\section{Proportionality}

The principle of proportionality would follow the same intrinsic logic suggested by Professor Lissitzyn in 1970. If the "costs are substantially outweighed by its benefits," the operation should not be launched. States should factor into this analysis not only their own national interests, but also the interests of the coastal State, third States, and those of the international community as a whole. Sir Quinlan further adds:

Constraint would accept that there are some methods of collection that must never be used, however severe we may judge the possible injury to be, and some that must not be used disproportionately - that is in circumstances where the breach of normal moral rules is more severe than the importance of the legitimate objective reasonably warrants. ${ }^{259}$

Proportionality is a relative term that is difficult to define. While considered a customary principle, "when faced with the need to implement it in practice its precise content becomes infamously elusive." 260 Nonetheless, as this Article has suggested, what is necessary is some form of a nuanced "balance of interests." Proportionality should therefore be examined, in part, in accordance with the political atmosphere surrounding the operation; ${ }^{261}$ the aims that stand at the heart of the decision to launch the surveillance operation; the likelihood of success of the operation; and the potential risks to minimum order goals and to intrusion on coastal States' rights in the exercise of the operation. As more cases come to light, and as more scholars apply the proportionality principle to them, the exact margins would begin to show. At the time being, one can at least raise questions as to the scope and intensity of U.S. surveillance operations in China's EEZ, China's surveillance operations in and around the South China Sea, as well as Russian operations near and above the Baltic Sea in recent years, and their meeting the standard of proportionality.

258. See GOLDSTEIN, supra note 80 , at 287 .

259. Michael Quinlan, Just Intelligence: Prolegomena to an Ethical Theory, 22(1) INTELLIGENCE \& NAT. SEC. 1, 6 (2007)

260. LUBELL, supra note 241, at 65 .

261. See Williams, supra note 52, at 58 ("A coastal state could consider foreign military maneuvers in its EEZ a threat of force, if the maneuvers were conducted in an atmosphere of high political tension and accompanied by tacit or overt demands."). 


\section{CONCLUDING REMARKS}

On a panel titled "Military Activities in the EEZ" moderated in 2009 by the Center for Oceans Law and Policy, Russian Professor of Law Alexander Skaridov criticized what he viewed as "artificial" attempts by scholars to resolve the EEZ surveillance conundrum through "narrowing, as much as possible, the freedom of military navigation." 262 Instead, he has contended, quite boldly, that the EEZ dispute must be:

[A]ddressed and resolved through the sometimes chaotic and unruly process whereby countries assert and defend their positions through state practices, followed by protests, by disagreeing countries, and then eventually by the give and take of diplomatic negotiations. Sooner or later consensus will emerge through this disorderly process. Already many sailors, pilots, and fishermen have died as nations assert their sometimes conflicting positions and jockey to put forward their views. It is to be hoped that violent conflicts can be kept to a minimum during the remainder of this law-making process. ${ }^{263}$

Professor Skaridov's criticism reminds me of the preface to Kant's "Perpetual Peace." Skaridov, in this case, is taking the role of the "practical politician," whereas I would seem to assume the position of the political theorist whose "empty ideas" are detached from worldly realities. This Article, however, and the ideas it puts forward are not naïve. I carefully worked to evade the trap of the "Hegelian impulse," if to use the words of Professor Radsan. ${ }^{264}$ It is important to remember that "[a]1l law requires political support. Principles of international law, like any prescription, are abrogated when their consumers and custodians decide, for better or worse to change them."265 All the international lawyer can do, as Reisman taught us, is "to participate in clarifying and formulating the common interest of the most comprehensive world community" 266 in the hopes of assisting future lawmakers in accomplishing their prescriptive tasks.

For most scholars who have examined the EEZ surveillance conundrum, the matter is exclusively understood through the lenses of the age-old rivalry between Hugo Grotius and John Selden over Mare Liberum (The Freedom of the Seas) and Mare Clausum (The Closing of the Seas), ${ }^{267}$ somewhat broadly construed. This Article should not be deemed as legitimizing attempts by coastal States to expand their maritime territorial bounds through "creeping jurisdiction." Rather, the framework proposed in

\footnotetext{
262. Skaridov, supra note 14 , at 252-53.

263. Id. at 258

264. See Radsan, supra note 173 , at 596

265. W. Michael Reisman, Holding the Center of the Law of Armed Conflict, 100 AM. J. INT'L L. 852,860 (2006).

266. Reisman, supra note 201 , at 350 .

267. For broader reading on the conflicting views between Grotious and Selden over the international legal regime of the seas, see WILHELM G. GREWE, THE EPOCHS OF INTERNATIONAL LAW 257-79 (2000).
} 
this Article steps outside the limits of classical international maritime law discourse to engage a completely different analysis, one which considers the EEZ surveillance issue as a microcosm through which to examine broader meta-questions about the regulation of intelligence, and of new surveillance technology. Some of the policy recommendations provided would seem to be of relevance to other intelligence-gathering fields, which I hope to further pursue in future works. In this regard, this Article is the first endeavor at a broader extrapolation of the International Law of Intelligence. 
